\title{
An overview of the Brazilian inselberg genus Ameroglossum (Linderniaceae, Lamiales), with the description of seven new species
}

\author{
Erton M. ALMEIDA ${ }^{1}$, Maarten J.M. CHRISTENHUSZ ${ }^{2, *}$, Artur Maia WANDERLEY ${ }^{3}$, \\ Joel Maciel P. CORDEIRO ${ }^{4}$, José Iranildo Miranda DE MELO ${ }^{5}$, \\ Fabiane Rabelo DA COSTA BATISTA ${ }^{6} \&$ Leonardo P. FELIX $^{7}$ \\ ${ }^{1}$ Laboratório de Citogenética e Evolução Vegetal, Departamento de Botânica, Centro de Biociências, \\ Universidade Federal de Pernambuco, Recife, Pernambuco, CEP: 50670-901, Brazil. \\ ${ }^{2}$ School of Molecular and Life Sciences, Curtin University, GPO Box U1987, \\ Perth WA 6845, Australia. \\ ${ }^{2}$ Plant Gateway, 5 Baddeley Gardens, Bradford BD10 8JL, UK. \\ ${ }^{3}$ Laboratório de Ecologia Vegetal Aplicada, Programa de Pós-Graduação em Biologia Vegetal, \\ Universidade Federal de Pernambuco, CEP: 50372-970 Recife, Pernambuco, Brazil. \\ ${ }^{4}$ Departamento de Geografia, Centro de Humanidade, Universidade Estadual da Paraíba, \\ Campus III, CEP: 58200-000, Guarabira, Paraíba, Brazil. \\ ${ }^{5}$ Universidade Estadual da Paraíba, Centro de Ciências Biológicas e da Saúde, Departamento \\ de Biologia, Campus I, Rua das Baraúnas, 351, CEP: 58429-500 Campina Grande, Paraíba, Brazil. \\ ${ }^{6}$ Instituto Nacional do Semiárido-INSA, Av. Francisco Lopes de Almeida, S/N, Bairro Serrotão, \\ Campina Grande, Paraíba, CEP: 58429-970, Brazil. \\ ${ }^{7}$ Departamento de Ciências Biológicas, Centro de Ciências Agrárias, Universidade Federal da Paraíba, \\ Campus II, CEP: 58397-000, Areia, Paraíba, Brazil.

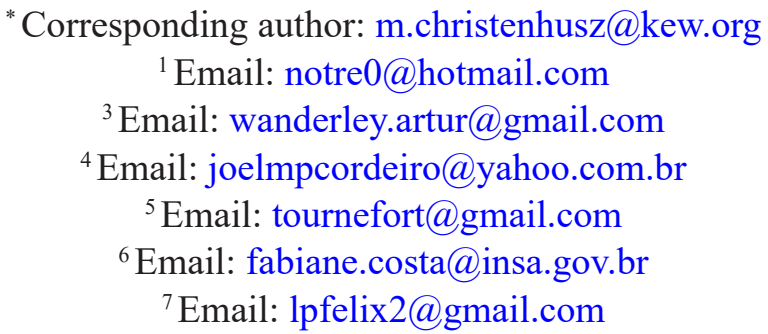

\begin{abstract}
Field studies of the inselberg flora of north-eastern Brazil have resulted in the discovery of much greater morphological diversity of the genus Ameroglossum, than previously envisaged. These enigmatic plants are endemic to isolated rock outcrops, which have long been surrounded by unsuitable habitat. The morphological forms are geographically isolated and stable in cultivation when grown under similar conditions. We here provide detailed descriptions of the two previously known species and propose an additional seven new species in the genus. A taxonomic revision of the genus, including an identification key is provided. We hypothesize that the evolution of this genus is driven by the diversity of their hummingbird pollinators. Due to the threatened nature of inselberg habitats and the small populations found for most taxa, the species described here are likely to be under threat and in need for formal redlisting.
\end{abstract}


Keywords. Borborema Plateau, co-evolution, endangered species, endemism, taxonomy.

Almeida E.M., Christenhusz M.J.M., Wanderley A.M., Cordeiro J.M.P., De Melo J.I.M., Da Costa Batista F.R. \& Felix L.P. 2021. An overview of the Brazilian inselberg genus Ameroglossum (Linderniaceae, Lamiales), with the description of seven new species. European Journal of Taxonomy 746: 1-25.

https://doi.org/10.5852/ejt.2021.746.1313

\section{Introduction}

On March 12, 1958, Dárdano de Andrade-Lima (coll. no. 50-600, IPA!) collected an unusual 'Scrophulariaceae' in Quipapá, Pernambuco State, Brazil. The specimen was found to be a new genus and tentatively called 'Dardanoa' by Vinicius Castro Souza on various herbarium specimens. This name was used, in advance of publication, by some regional botanists who were aware of this proposal. However, this name was never formally published. In 1998, the German botanist Stefan Vogel visited Pernambuco and together with the Brazilian botanist Ariadna Lopes collected material of the same genus at Brejo da Madre de Deus. Specimens of the collected material were described as the genus Ameroglossum Eb.Fisch., S.Vogel \& A.V.Lopes (Fischer et al. 1999) based on its undivided lip [etymology: from

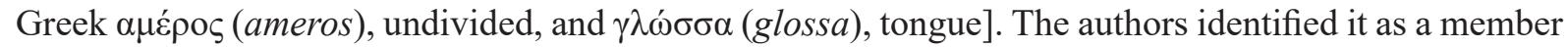
of Scrophulariaceae, with relationships to Russelia Jacq. (now Plantaginaceae), Hemichaena Benth. (now Phrymaceae) and Eremogeton Standl. \& L.O.Williams (now Scrophulariaceae). It was later also compared to Penstemon Schmidel (now Plantaginaceae) (Souza \& Giulietti 2009), although it differed from all these genera in many characters, and its true relationships remained obscure.

Preliminary molecular and morphological studies (in preparation) suggest that Ameroglossum is related to Cubitanthus Barringer (1984) and Stemodiopsis Engler (1897), formerly placed in Gesneriaceae and Scrophulariaceae, respectively. These genera are now known to belong to Linderniaceae (Fischer et al. 2013; Christenhusz et al. 2017), and several characters appear to be shared by Ameroglossum and this clade (Almeida et al. 2019). A molecular phylogenetic study of Linderniaceae with a focus on these taxa is currently in progress by researchers from Brazil, China and the UK.

Ameroglossum is endemic to inselbergs associated with the Borborema Plateau in north-eastern Brazil, especially in the central-eastern region of the Plateau (Almeida et al. 2016, 2019). Populations are small and geographically isolated, occurring only within small vegetation 'islands' typical of rock outcrops, with flowers pollinated by hummingbirds (ornitophilia) and barochoric dispersal of seeds (Wanderley et al. 2014a). Its species have been suggested to exhibit interpopulational genetic and phenotypic variation (differences in plant architecture and leaf and flower size) due to environmental factors and geographic distances (Wanderley et al. 2014a, 2018).

Due to the interest in genetic and cytological diversity of inselberg plants, extensive field work has been carried out in north-eastern Brazil. Diversity of the genus Ameroglossum has been found to be much greater than initially thought. One species was published first as A. manoelfelixii L.P.Felix \& E.M.Almeida (in Almeida et al. 2016), which differs in the winged quadrangular stems, glabrous vegetative segments, quadrangular pedicels, and the red corolla with purple trichomes in the median lobe of the lower lip. Several unusual specimens were found, including two new putatively related genera in Linderniaceae, which were described as Catimbaua L.P.Felix, Christenh. \& E.M.Almeida and Isabelcristinia L.P.Felix, Christenh. \& E.M.Almeida (in Almeida et al. 2019), with the latter genus having the greatest affinity to Ameroglossum in preliminary molecular studies (not presented here). In addition to these two new genera, many new populations of Ameroglossum have been discovered, which exhibit a greater morphological diversity than previously known. A number of populations represent undescribed species, which follows the trend of recent taxonomic discoveries from the inselbergs in 
north-eastern Brazil (e.g., Pontes 2012; Cordeiro et al. 2018; Cardoso et al. 2019a, 2019b; de Lima et al. 2019; Santos et al. 2019; Morales \& Morais 2020; Morales \& Kollmann 2020), showing that this often taxonomically neglected region of Brazil has a greater diversity than previously assumed.

The possible shift from bee pollination (as in Isabelcristinia aromatica L.P.Felix \& E.M.Almeida in Almeida et al. 2019) to hummingbird pollination (Ameroglossum), or vice versa, may have driven the evolution of this genus group (e.g., Castellanos et al. 2004; Cronk \& Ojeda 2008; Thomson \& Wilson 2008; Zung et al. 2015; Kriebel et al. 2020). Following ecological studies on Ameroglossum pernambucense Eb.Fisch., S.Vogel \& A.V.Lopes (Wanderley et al. 2014a), we hypothesize that each species of Ameroglossum is pollinated by a different species of hummingbird.

The newly discovered populations of Ameroglossum show a great morphological diversity, some clearly belonging to the two published taxa, but seven populations could not be placed satisfactorily in these species. Therefore, these new species are described below, increasing to nine the number of species in Ameroglossum. An amended description of Ameroglossum and a diagnostic key to the species are provided.

\section{Material and methods}

Field collections were undertaken on rock outcrops in the geomorphological structure of the Borborema Plateau, which covers parts of the Brazilian states of Rio Grande do Norte, Paraíba, Pernambuco and Alagoas (Fig. 1). The Borborema Plateau corresponds to a group of continuous highlands distributed along the eastern section of north-eastern Brazil, to the north of the São Francisco River, with elevations often exceeding $800 \mathrm{~m}$ (Corrêa et al. 2010). The predominant vegetation in that region is caatinga (thorny, dry-deciduous vegetation). A semi-arid climate that is susceptible to humid coastal winds on its eastern flank allows the development of enclaves of humid vegetation (called brejos de altitude; Andrade-Lima 1981).

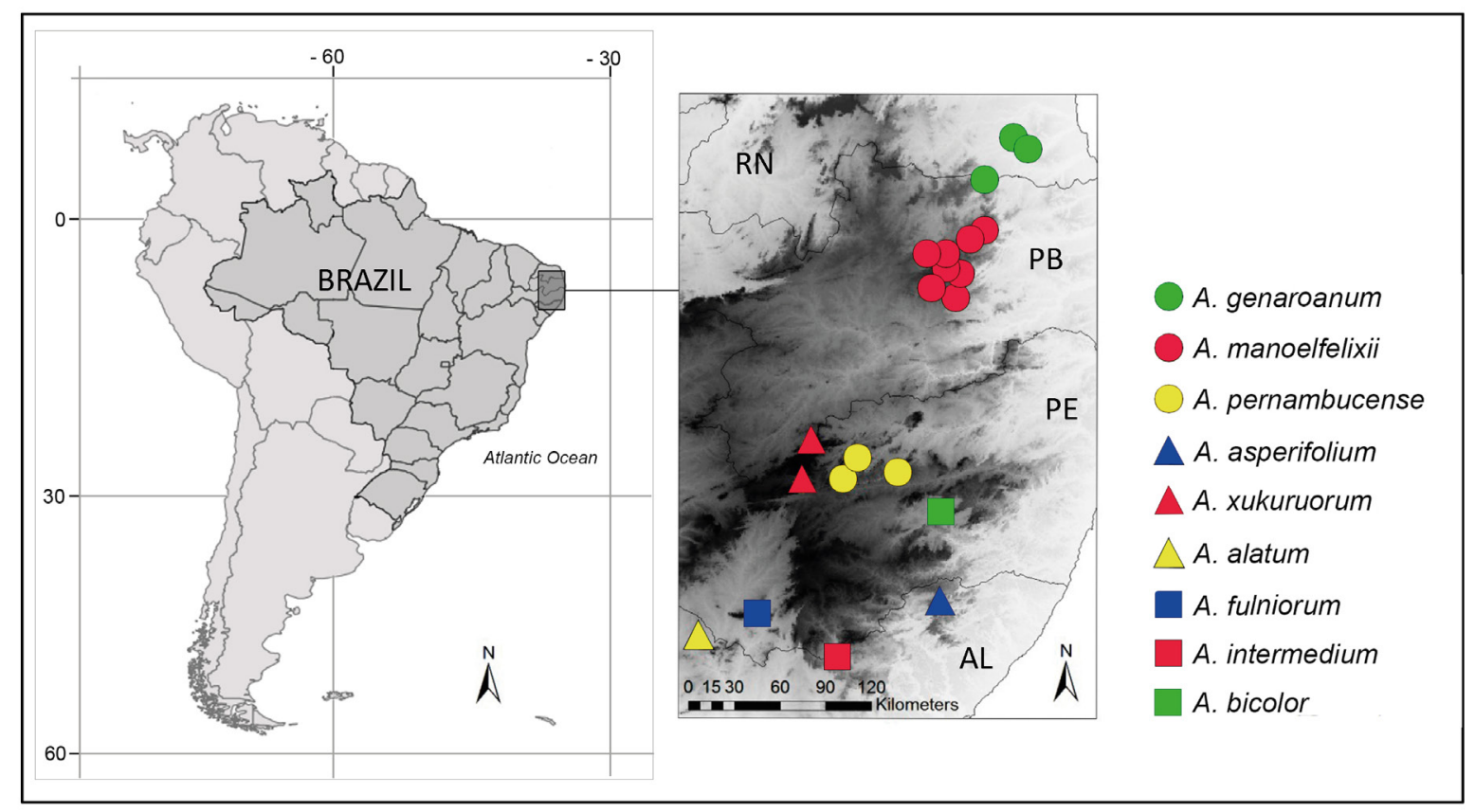

Fig. 1. Geographic localization and distribution of the genus Ameroglossum Eb.Fisch., S.Vogel \& A.V.Lopes and its respective species. Abbreviations: $\mathrm{AL}=$ Alagoas; $\mathrm{PB}=$ Paraíba; $\mathrm{PE}=$ Pernambuco; $\mathrm{RN}=$ Rio Grande do Norte. 
Morphological analyses were based on material preserved in $70 \%$ alcohol, as well as on live plants grown in the experimental garden of the Plant Cytogenetic Laboratory of the Agricultural Sciences Centre of the Federal University of Paraíba. Descriptions of the morphological characters are based on terminology proposed by Gonçalves \& Lorenzi (2007) and Radford et al. (1974) for general terminology and on Payne (1978) for trichome morphology. Important herbarium collections were consulted, but not all historical material was studied, because many collections were inaccessible due to the COVID-19 pandemic. It is therefore possible that additional undescribed species are hiding among this material.

Acronyms of herbaria follow Index Herbariorum (Thiers, continuously updated).

\title{
Results
}

\author{
Class Equisetopsida C.Agardh \\ Subclass Magnoliidae Novák ex Takht. \\ Superorder Asteranae Takht. \\ Order Lamiales Bromhead \\ Family Linderniaceae Borsch, Kai Müll. \& Eb.Fisch. \\ Genus Ameroglossum Eb.Fisch., S.Vogel \& A.V.Lopes
}

Feddes Repertorium 110 (7-8): 529 (Fischer et al. 1999), here amended.

\section{Type species}

Ameroglossum pernambucense Eb.Fisch., S.Vogel \& A.Lopez.

\section{Description}

Saxicolous, perennial chamaephytes, bases of stems slightly woody; plants up to $3 \mathrm{~m}$; branching principally from the stem base, often secondarily branched irregularly along the stem. Young branches greenish to purplish, lustrous to dull, erect, quadrangular or cylindrical, thick, angular, often winged, glabrous, glabrescent, pubescent or villous, with trichomes aciculate, recurved, bifid or papillose; brownish to cinereous when mature, slightly inclined to incumbent, subquadrangular to cylindrical, not winged, glabrous, slightly lignified. Leaves sessile; opposite decussate or verticillate; leaf blade green to reddish or purplish, bifacial, rarely slightly cinereous, lustrous, rarely dull, lanceolate, narrowly elliptic, trullate, elliptic to ovate, smooth to strongly bullate; venation camptodromous; adaxial side with venation reticulate, impressed, glabrous to pubescent, with trichomes recurved or rarely papillose; abaxial side with venation reticulate, emergent, indumented principally on the venation, glabrescent, pubescent or villose, with trichomes aciculate, recurved, bifid ramified, glandular or papillose; base slightly decurrent in all species; apex acute, acuminate, slightly caudate to cirrhose, flat to recurved; margin serrate, flat to revolute, glabrous to ciliate, with trichomes recurved, rarely short aciculate. Inflorescence axillary, in simple or compound dichasia, rarely flowers single. Peduncles green to reddish, rarely bifacial, linear, cylindrical to subcylindrical, winged to wingless, glabrous, glabrescent, pubescent to villous, with trichomes aciculate, recurved, bifid or papillose. Pedicels green to reddish, frequently with base curved upwards, recurved after fertilization, subcylindrical, glabrous, glabrescent, pubescent to villous, with trichomes aciculate, recurved, bifid or papillose; dorsal side winged, ventral side varying from winged to wingless. Bracts green or tinged red, slightly cymbiform, inflexed; adaxial side glabrous to glabrescent, with trichomes papillose, rarely aciculate; abaxial side glabrous, glabrescent to pubescent, with trichomes aciculate, recurved, bipinnate or papillose; margin glabrous or ciliate, with recurved trichomes. Bracteoles present. Calyx green to purplish, rarely with apex reddish, pentamerous, gamosepalous, slightly asymmetrical; sepals lanceolate to broad-lanceolate, rarely ovate, dorsal sepal rarely overlapping lateral sepals, wingless or rarely winged by the prolongation of the 
wings of the pedicel; lateral abaxial side glabrous to pubescent with trichomes aciculate, recurved, bifid or papillose; adaxial side with trichomes papillose, rarely recurved; margin glabrous or ciliate, with recurved trichomes. Corolla scarlet to orange-yellow, sometimes with ventral or proximal third yellow, pentamerous, tubular, sometimes with wide base, zygomorphic, bilabiate, symmetrical; externally glabrous to pubescent, trichomes papillose, glandular, aciculate or recurved; internal side glabrous to glabrescent, trichomes papillose; upper lip bilobed to slightly bilobed, margin with violet border, revolute, principally at the apical portion; lower lip yellow, rarely with scarlet margins, slightly trilobed, with borders of the inner perianth densely pubescent, trichomes aciculate conical or filiform, white, yellowish white or violet; lobes revolute or involute, lateral lobes smaller; median lobe ovate to elongated. Stamens 4, didynamous, included or exserted, epipetalous, adnate to the distal median third of the corolla tube; filaments violet or white, glabrescent, covered by short glandular trichomes, principally on the distal third; anthers bithecous, thecae blackish, rounded; pollen blue, pulvinate; staminodium filiform, adnate from the proximal third to the middle of the corolla tube, glabrous to glabrescent, trichomes short glandular, rarely papillose. Ovary conical, laterally compressed, bilocular, pluri-ovulate, glabrous, rarely glabrescent, trichomes papillose and/or aciculate, base enveloped by an aneliform nectariferous disk; nectar transparent, abundant, sweet; style violet, terminal, exserted to enclosed, glabrous, rarely glabrescent, trichomes aciculate or papillose, principally on the proximal third; stigma capitate. Capsule green to purplish, conical, dehiscent; valves 2, pluriseminate, glabrous; calyx and style persistent. Seeds brownish, subreniform, longitudinal costae striate-undulate.

Ameroglossum is restricted to north-eastern Brazil (so far reported in the states of Alagoas, Paraíba, Pernambuco and Rio Grande do Norte). It comprises nine species and is morphologically similar to Cubitanthus, Catimbaua, Isabelcristinia and the African Stemodiopsis. A key to the species of Ameroglossum, Isabelcristinia, Catimbaua and Cubitanthus is provided below.

\section{Note}

The inflorescence was described by Fischer et al. (1999) as a frondose thyrse, which was based on the little material that was available to them at the time. However, this description of the inflorescence is incorrect. We have observed in cultivated material that when inflorescences are initiated, the plant produces inflorescence buds in the axils of leaves in the upper part of the main stems, which grow into inflorescences. These leafy stems can continue to grow for more than one flowering season. Therefore, the inflorescence is not a thyrse, but the inflorescences are axillary simple or compound dichasia.

\section{Key to the species of Ameroglossum and related genera}

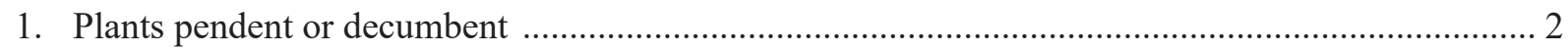

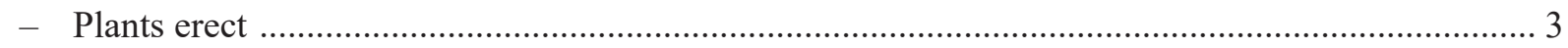

2. Leaves with arachnoid indumentum; flowers red, with tube larger than the lips

Catimbaua pendula L.P.Felix \& E.M.Almeida

- Leaves with pubescent indumentum; flowers white, with tube smaller than the lips

Cubitanthus alatus (Cham. \& Schltdl.) Barringer

3. Plants aromatic; leaves sticky, indumentum composed of glandular trichomes; corolla personate (masked)

Isabelcristinia aromatica L.P.Felix \& E.M.Almeida

- Plants without aroma; leaves not sticky, indumentum without glandular trichomes; corolla tubular

(Ameroglossum) ...4

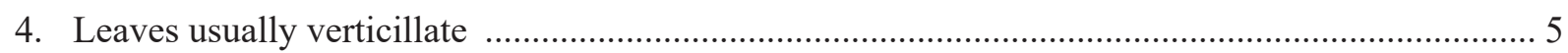

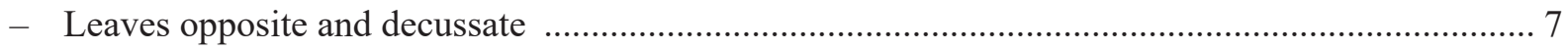


5. Lower lip of the corolla with inner perianth covered by filiform trichomes and with revolute lobes Ameroglossum intermedium E.M.Almeida, A.M.Wanderley \& L.P.Felix sp. nov.

- Lower lip of the corolla with inner perianth covered by conical trichomes and with involute lobes

6. Branches puberulent; leaf blade with densely reticulated venation, puberulent on abaxial side Ameroglossum pernambucense Eb.Fisch., S.Vogel \& A.V.Lopes

- Branches glabrescent; leaf blade with sparsely reticulated venation, glabrous to glabrescent on abaxial side Ameroglossum xukuruorum E.M.Almeida, Christenh. \& L.P.Felix sp. nov.

7. Peduncles winged

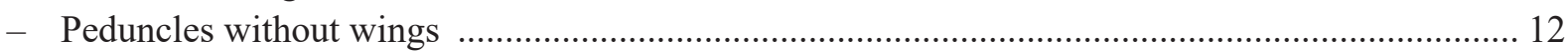

8. Young leaves rugose on the adaxial side, pubescent; calyx with two dorsal wings

Ameroglossum asperifolium E.M.Almeida, J.M.P.Cordeiro \& L.P.Felix sp. nov.

- Young leaves smooth adaxially, glabrous to glabrescent; calyx not winged

9. Branches dull, peduncle and pedicel pubescent, not glandular

Ameroglossum intermedium E.M.Almeida, A.M.Wanderley \& L.P.Felix sp. nov.

- Branches lustrous, peduncle and pedicel glabrous or sparsely pubescent with short, glandular trichomes

10. Inflorescence a compound dichasium

Ameroglossum bicolor E.M.Almeida, A.M.Wanderley \& L.P.Felix sp. nov.

- Inflorescence a simple dichasium

11. Branches, leaves and calyx purplish; flowers with scarlet corolla

Ameroglossum fulniorum E.M.Almeida, A.M.Wanderley \& L.P.Felix sp. nov.

- Branches, leaves and calyx predominately green, flowers with orange corolla

Ameroglossum alatum E.M.Almeida, A.M.Wanderley \& L.P.Felix sp. nov.

12. Plants densely branched; stem, leaves, peduncle, pedicel and calyx green; leaves principally ovate; flowers orange .....Ameroglossum genaroanum E.M.Almeida, J.M.P.Cordeiro \& L.P.Felix sp. nov.

- Plants sparsely branched; stem, leaves, peduncle, pedicel, and calyx purplish to slightly purplish; leaves narrowly elliptic; flowers scarlet ....Ameroglossum manoelfelixii L.P.Felix \& E.M.Almeida

\section{Ameroglossum alatum E.M.Almeida, A.M.Wanderley \& L.P.Felix sp. nov.} urn:lsid:ipni.org:names:77216325-1

Figs $2 \mathrm{~A}, 3 \mathrm{a}-\mathrm{e}$

\section{Diagnosis}

A species morphologically similar to A. manoelfelixii because it has glabrous to glabrescent, lustrous vegetative parts and inflorescences. However, A. alatum sp. nov. differs from this and other species of Ameroglossum, by having conspicuous membranous wings on the stem extending to the peduncle of the inflorescence and the pedicel (vs not or sparsely winged). Because of its green stems and leaves, A. alatum sp. nov. may also appear similar to A. bicolor sp. nov., although it differs by having its inflorescence in a simple dichasium (vs compound dichasium), winged peduncles and pedicels (vs partially winged) and the sepals not overlapping (vs sepals overlapping). 


\section{Etymology}

The name is derived from the Latin adjective 'alatus', 'winged', referring to the conspicuous wings on the branches, peduncles and pedicels.

\section{Material examined}

\section{Type}

BRAZIL - Alagoas • Maravilha; 09¹4'39" S, 37¹9'33" W; 792 m a.s.1.; 21 Aug. 2012; E.M. Almeida \& A.M. Wanderley 461; holotype: EAN!; isotype: K!.

\section{Description}

Saxicolous chamaephyte up to $80 \mathrm{~cm}$, with secondary branching in the medial portion. Young branches greenish to slightly purplish, lustrous, quadrangular, conspicuously winged, glabrous; brownish when mature, slightly inclined, subquadrangular. Leaves opposite, decussate; leaf blade 3.5-6.0 × 1.5-2.5 cm, green with purplish margins, lustrous, elliptic to narrowly elliptic, slightly bullate; adaxial side glabrous; abaxial side with venation occasionally purplish, glabrescent with papillose trichomes, rarely aciculate; apex acute, rarely slightly caudate, reflexed; margin flat, occasionally revolute, ciliate. Inflorescence a simple dichasium. Peduncle purplish, frequently bifacial, subcylindrical, conspicuously winged, glabrescent, with papillose trichomes; primary peduncle $0.60-1.70 \times 0.10-0.12 \mathrm{~cm}$, secondary peduncle $0.20-0.80 \times 0.06-0.07 \mathrm{~cm}$. Pedicel $0.60-1.40 \times 0.09-0.13 \mathrm{~cm}$, greenish, frequently bifacial, glabrescent, with papillose trichomes; dorsal side conspicuously winged, ventral side with base slightly winged. Bracts $0.25-0.40 \times 0.06 \mathrm{~cm}$, slightly purplish, glabrescent, with papillose trichomes, margin glabrous. Calyx greenish, occasionally with reddish apex, abaxial side glabrous, adaxial side densely covered by papillose trichomes, margin glabrous; sepals lanceolate, dorsal ones 1.10-1.20 × $0.30-0.35 \mathrm{~cm}$; lateral ones ca $1.0 \times 0.2 \mathrm{~cm}$; ventral ones ca $1.0 \times 0.3 \mathrm{~cm}$. Corolla $4.0-4.5 \mathrm{~cm}$ long, orangish, externally pubescent, with papillose trichomes and/or glandular, internally glabrous; tube $2.8-3.3 \mathrm{~cm}$ long; upper lip $1.2-1.3 \times 0.6 \mathrm{~cm}$, slightly bilobate; lower lip $1.0-1.2 \times 0.5 \mathrm{~cm}$, inner perianth with filiform trichomes, white, lobes revolute, median lobe ca $0.10 \times 0.13 \mathrm{~cm}$. Stamens included, adnate to the middle of the corolla tube; filaments violet, ca $2.0 \mathrm{~cm}$ long; capsule ca $0.1 \mathrm{~cm}$ diam.; staminodium ca $0.6 \mathrm{~cm}$ long, adnate to the middle of the corolla tube, glabrous. Ovary $0.6-0.7 \times 0.3 \mathrm{~cm}$; style ca $4.6 \mathrm{~cm}$ long, exserted, glabrous. Capsule $1.5-1.7 \times 0.7-0.9 \mathrm{~cm}$, green. Seeds $0.10 \times 0.05 \mathrm{~cm}$.

\section{Distribution}

Currently known only from a single population on a granite outcrop near the city of Maravilha, in the Sertão Alagoano mesoregion, Alagoas State, Brazil. Elevation ca 790 m.

\section{Ecology}

As for the other taxa of Ameroglossum, A. alatum sp. nov. is restricted to granite outcrops, where it is probably pollinated by hummingbirds. Flowering and fruiting were recorded in August.

\section{Population and threats}

The population is composed of approximately 20 adult individuals, restricted to an area of approximately $3000 \mathrm{~m}^{2}$ on one of the tops of this granite outcrop. The small population demonstrates elevated homozygosity, suggesting a low genetic diversity, probably caused by a founder and/or a genetic bottleneck effect (Wanderley et al. 2018). 


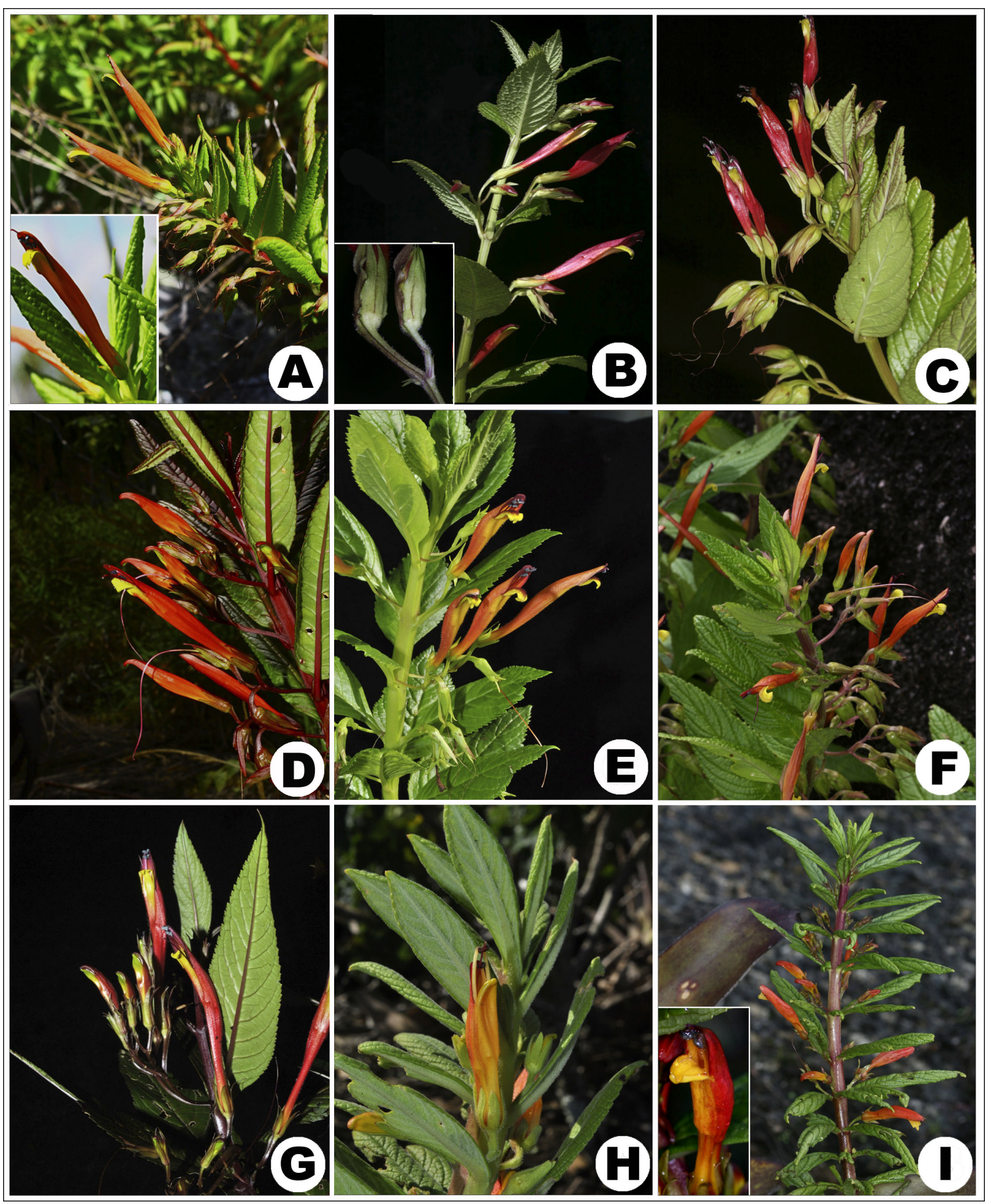

Fig. 2. Reproductive branches and floral details of different taxa of the genus Ameroglossum Eb.Fisch., S.Vogel \& A.V.Lopes. A. A. alatum sp. nov. B. A. asperifolium sp. nov. C. A. bicolor sp. nov. D. A. fulniorum sp. nov. E. A. genaroanum sp. nov. F. A. intermedium sp. nov. G. A. manoelfelixii L.P.Felix \& E.M.Almeida. H. A. pernambucense Eb.Fisch., S.Vogel \& A.V.Lopes. I. A. xukuruorum sp. nov. 
Ameroglossum asperifolium E.M.Almeida, J.M.P.Cordeiro \& L.P.Felix sp. nov. urn:lsid:ipni.org:names:77216326-1

Figs $2 \mathrm{~B}, 3 \mathrm{f}-\mathrm{k}$

\section{Diagnosis}

This species is distinguished by the presence of two conspicuous wings on the dorsal sepal (vs calys without wings in all other species). It also has leaves that are rough to the touch with aciculate hairs (vs glabrous or softly hairy in all other species).

\section{Etymology}

The epithet derives from the Latin 'asper', 'rough', and 'folium', 'leaf', reflecting the rough texture the leaves of this species.

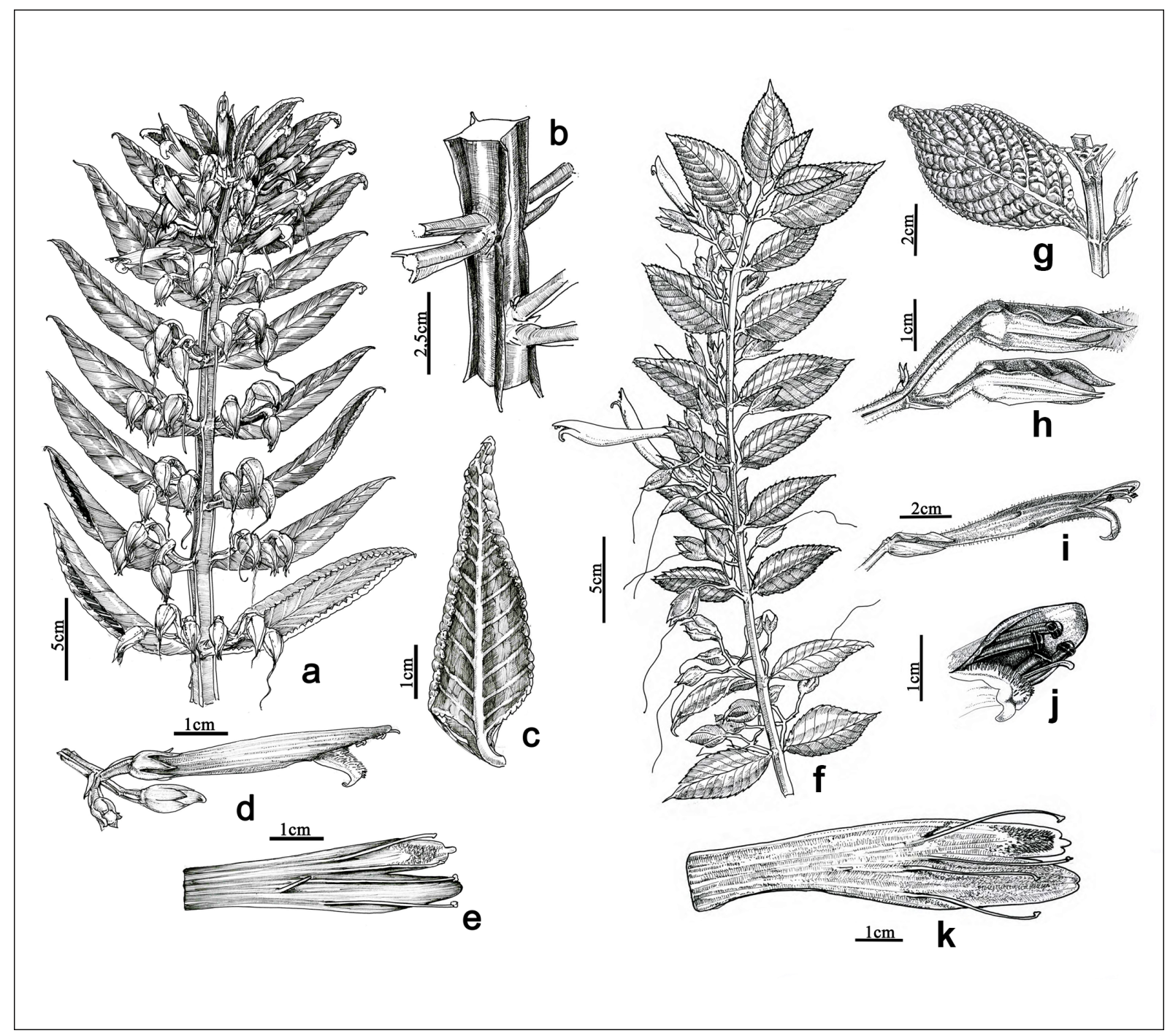

Fig. 3. a-e. Ameroglossum alatum sp. nov. (Almeida \& Wanderley 461). a. Reproductive branches. b. Stem. c. Leaf, abaxial side. d. Inflorescence. e. Corolla opened, showing the stamens. f-k. Ameroglossum asperifolium sp. nov. (Felix et al. 15160). f. Reproductive branches. g. Leaf, adaxial side. h. Inflorescence, showing the calyx. i. Flower. j. Flower, showing the stamens. k. Corolla opened, showing the stamens. 


\section{Material examined}

Type

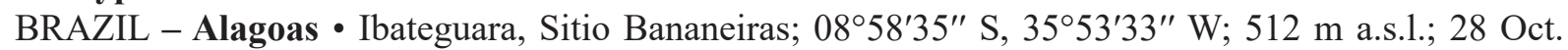
2014; L.P. Felix, E.M. Almeida, J.P. Araújo, J.M.P. Cordeiro 15160; holotype: EAN!; isotypes: IMA!, IPA!, K!, RB!.

\section{Paratype}

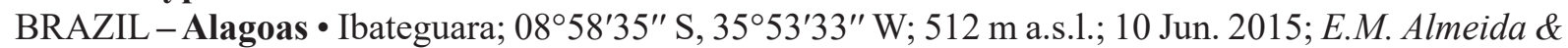
A.M. Wanderley 1572; EAN[23212]!.

\section{Description}

Saxicolous chamaephyte up to ca $1 \mathrm{~m}$, rarely with secondary branching. Young branches purplish, lustrous, quadrangular, not winged, pubescent, with aciculate trichomes; branches brownish when mature, slightly inclined, subquadrangular. Leaves opposite, decussate; leaf blade 4.0-16.0 × 1.7$5.5 \mathrm{~cm}$, purplish when young, later green with purplish margin, lustrous, elliptic to ovate, strongly bullate; adaxial side pubescent, with aciculate trichomes; abaxial side glabrescent, with recurved trichomes; apex acute to acuminate, flat; margin flat, ciliate. Inflorescence a simple dichasium. Peduncle purplish, subcylindrical, winged, pubescent, with trichomes recurved and papillose; primary peduncle $0.65-2.10 \times 0.08-0.17 \mathrm{~cm}$, secondary peduncle $0.40-0.75 \times 0.08-0.17 \mathrm{~cm}$. Pedicel $0.60-1.50 \times 0.14-$ $0.20 \mathrm{~cm}$, purplish, pubescent, with trichomes recurved and papillose; ventral side with wings on the proximal third to totally winged. Bracts $0.20-0.50 \times 0.06-0.08 \mathrm{~cm}$, purplish; abaxial side glabrescent, trichomes recurved, adaxial side glabrescent, trichomes papillose, margin ciliate with recurved trichomes. Calyx purplish, abaxial side glabrescent, with aciculate trichomes, recurved and papillose, adaxial side densely covered by papillose trichomes, rarely recurved, margin glabrous; dorsal sepal $1.9-2.4 \times 0.5-0.7 \mathrm{~cm}$, widely lanceolate, winged; lateral sepals $1.6-2.1 \times 0.3-0.5 \mathrm{~cm}$, lanceolate; ventral sepals $1.5-2.0 \times 0.3-0.4 \mathrm{~cm}$, lanceolate. Corolla $5.5-7.0 \mathrm{~cm}$ long, scarlet, externally pubescent, with glandular trichomes; internal side glabrescent, with papillose trichomes; tube 4.3-5.9 cm long; upper lip $1.2-1.7 \times 0.8-1.1 \mathrm{~cm}$, slightly bilobate; lower lip $1.1-1.6 \times 0.5-0.6 \mathrm{~cm}$, inner perianth with trichomes filiform, violet; lobes revolute; median lobe $0.20-0.27 \times 0.08-0.10 \mathrm{~cm}$. Stamens included, adnate to the median third of the corolla tube; filaments violaceous, dorsal ones $1.8-2.6 \times 0.08 \mathrm{~cm}$; ventral ones $2.0-2.9 \times 0.08 \mathrm{~cm}$; anthers $0.15 \mathrm{~cm}$ diam.; staminodium $0.17-0.20 \mathrm{~cm}$, adnate until the middle third of the corolla tube, glabrous. Ovary ca $0.7 \times 0.3 \mathrm{~cm}$, glabrescent, with trichomes papillose and/or aciculate; style 5.0-6.0 cm, occasionally exserted, glabrous. Capsule 1.5-2.0 $\times 0.6-0.8 \mathrm{~cm}$, slightly purplish. Seeds $0.10 \times 0.05 \mathrm{~cm}$.

\section{Distribution}

Ameroglossum asperifolium sp. nov. is known only from a small population growing on a granite outcrop where it covers an area of approximately 0.5 ha in the Leste Alagoano mesoregion, Alagoas State, Brazil. Elevation ca $510 \mathrm{~m}$.

\section{Ecology}

Flowering and fruiting was observed in June and October. The rocky outcrop where the species was collected is located at the edge of a secondary road near the Usina Serra Grande sugarcane plantation, Alagoas State, and was probably originally surrounded by Atlantic Forest vegetation.

\section{Population and threats}

There is only a single known isolated population of this species, occupying an area of less than $10 \mathrm{~km}^{2}$. In addition to the degradation of the surrounding habitat due to agricultural expansion, we observed invasion of the outcrop by Furcraea foetida (L.) Haw. (Asparagaceae), resulting in competition for space and consequent reduction of the population of this newly described taxon. 
Ameroglossum bicolor E.M.Almeida, A.M.Wanderley \& L.P.Felix sp. nov. urn:lsid:ipni.org:names:77216327-1

Figs $2 \mathrm{C}, 4 \mathrm{a}-\mathrm{c}$

\section{Diagnosis}

This species is morphologically similar to A. alatum sp. nov. in having lustrous branches and leaves, winged pedicels, and white trichomes on the lower lip of the corolla tube. It differs in having green or slightly purplish vegetative portions (vs completely green), wings not evident (vs strongly winged), inflorescence usually a compound dichasium (vs simple dichasium) and the dorsal sepal partially covering the lateral sepals (vs the sepals not overlapping).

\section{Etymology}

The specific epithet is the Latin adjective 'bicolor', 'two-colored', referring to the vegetative variation observed in its populations. Among the four populations described here, it was possible to encounter green or purplish, almost wine-coloured, plants in the same population, a characteristic only observed in this species.
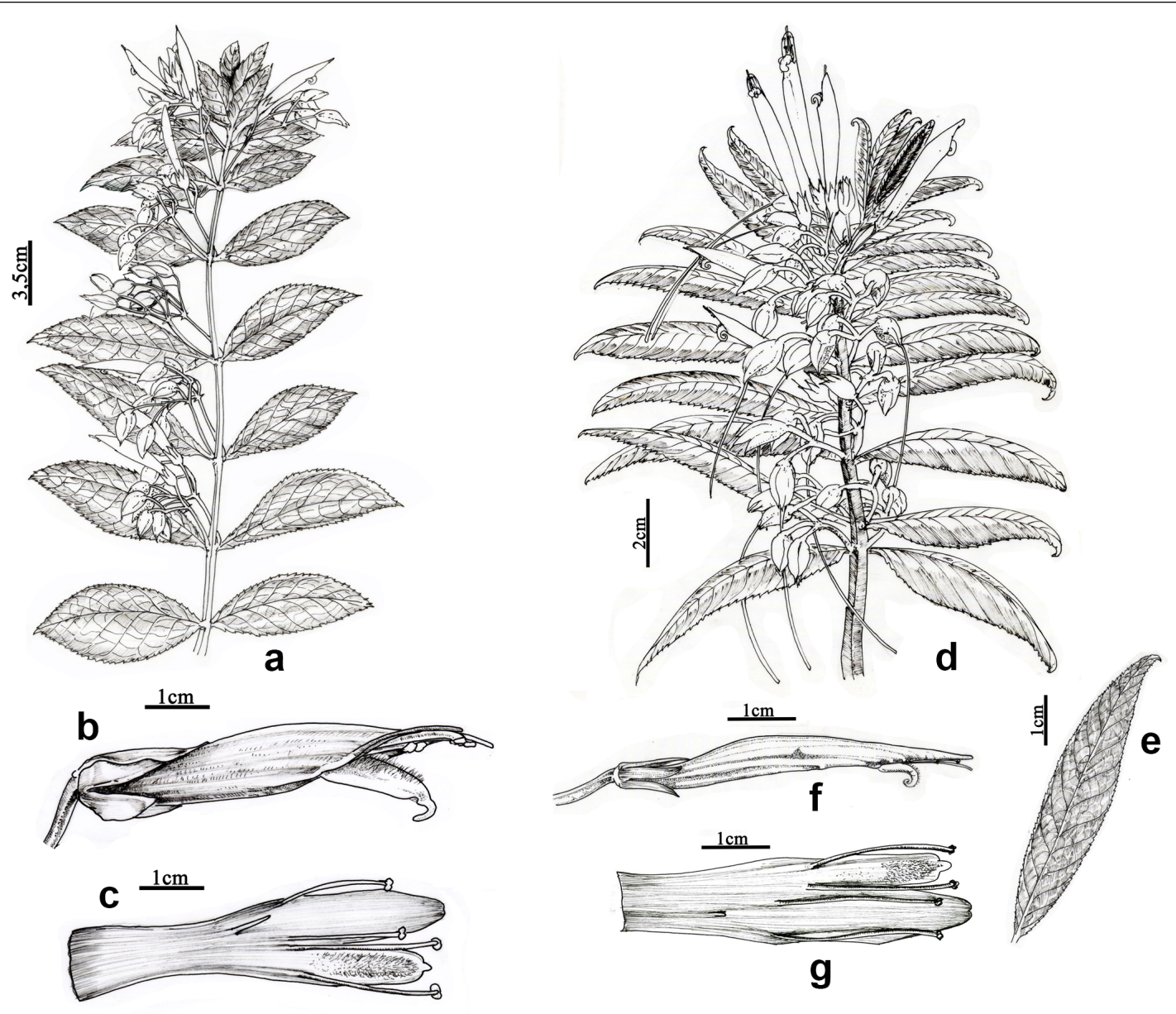

Fig. 4. a-c. Ameroglossum bicolor sp. nov. (Almeida et al. 1229). a. Reproductive branches. b. Flower. c. Corolla opened, showing the stamens. d-g. Ameroglossum fulniorum sp. nov. (Almeida \& Wanderley 439). d. Reproductive branches. e. Leaf, adaxial side. f. Flower. g. Corolla opened, showing the stamens. 


\section{Material examined}

\section{Type}

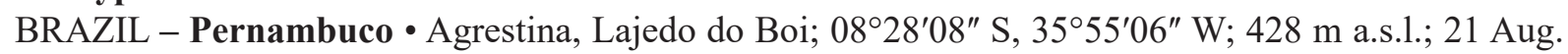
2014; E.M. Almeida, E.M. Almeida \& M. Fernandes 1229; holotype: EAN!; isotypes: IPA!, K!, RB!, UFP!.

\section{Paratypes}

BRAZIL - Pernambuco - Caruaru, Pedra do Guariba; 29 Jul. 2005; Y. Melo, M. Alves, P. Santos, A. Araújo, J. Rodrigues, J. Gomes, S. Martins \& B. Maciel 43; UFP[41,995]! • Pedra do Guariba; $08^{\circ} 22^{\prime} 55^{\prime \prime}$ S, 35 50'38" W; 685 m a.s.1.; 22 Jul. 2007; M. Sobral-Leite, B. Maciel \& P. Gomes 359; UFP[46,440]! • "Pedra do Guariba"; 08²2'55" S, 3550'38" W; 685 m a.s.1.; 22 Jul. 2007; M. SobralLeite, B. Maciel \& P. Gomes 382; IPA[80,821]! • Divisa entre os municípios de Caruaru e Agrestina,

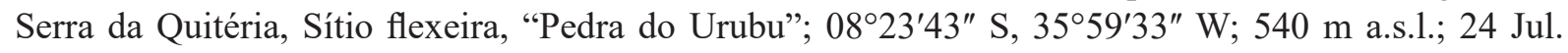
2009; M. Sobral-Leite, B. Maciel \& P. Gomes 916; UFP[57,163]! • "Pedra do Urubu"; 08²3'43" S, 3559'33" W; 540 m a.s.1.; 24 Jul. 2009; M. Sobral-Leite, B. Maciel \& P. Gomes 916; IPA[83,689]! • Agrestina, Distrito de Terra Vermelha, Pedra do Urubu; ca 700 m a.s.1.; 2 Aug. 2009; A.M.Wanderley 1;

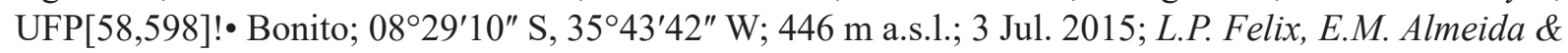
J.P. Araújo 15758; EAN[22,895]! • Quipapá; 12 Mar. 1958; Dárdano de Andrade-Lima 50-600; IPA!.

\section{Description}

Saxicolous chamaephyte up to $80 \mathrm{~cm}$, with frequent secondary branching along the stem. Young branches purplish or greenish, lustrous, quadrangular, not winged, glabrescent, trichomes aciculate and papillose, principally near the insertion of the young leaves; branches brownish when mature, slightly inclined to incumbent, subquadrangular. Leaves opposite, decussate; leaf blade 3.4-9.1 $\times 1.0-3.8 \mathrm{~cm}$, green and tinged with purple when young, bullate, later green to greenish, smooth, lustrous, elliptic, rarely narrowly elliptic; adaxial side glabrous; abaxial side glabrescent, trichomes recurved and/or papillose; apex acute, rarely acuminate, flat; margin flat, occasionally revolute, ciliate. Inflorescence a compound dichasium, occasionally simple. Peduncle green or slightly purplish, subcylindrical, winged to the median third, glabrescent, with papillose trichomes; primary peduncle $0.9-3.0 \times 0.1-0.2 \mathrm{~cm}$, secondary peduncle $0.45-1.40 \times 0.06-0.15 \mathrm{~cm}$, tertiary peduncle $0.36-0.80 \times 0.06-0.09 \mathrm{~cm}$. Pedicel $0.6-1.3 \times$ $0.06-0.10 \mathrm{~cm}$, green or tinged purple, ventral portion not winged, glabrous. Bracts $0.20-0.60 \times 0.05-$ $0.10 \mathrm{~cm}$, green or tinged purple, glabrescent, with papillose trichomes, margin glabrous. Calyx greenish to slightly purplish, abaxial side glabrescent, with trichomes papillose, rarely aciculate, adaxial side densely covered by papillose trichomes, margin glabrous; dorsal sepal $1.5-2.1 \times 0.5-0.7 \mathrm{~cm}$, broadly lanceolate to ovate, partially covering the lateral sepals; lateral sepals $1.2-1.6 \times 0.2-0.3 \mathrm{~cm}$, lanceolate; ventral ones $1.5-1.3 \times 0.3-0.4 \mathrm{~cm}$, lanceolate. Corolla $4.4-5.2 \mathrm{~cm}$ long, yellow-orange or scarlet, externally pubescent, with trichomes glandular and/or papillose, internally glabrous; tube $3.2-4.0 \mathrm{~cm}$ long; upper lip 1.2-1.4 ×0.8-0.9 cm, slightly bilobate; lower lip 0.9-1.3 $\times 0.4-0.5 \mathrm{~cm}$, inner perianth with trichomes filiform, white; lobes revolute, median lobe $0.13-0.15 \times 0.06-0.07 \mathrm{~cm}$. Ventral pair of stamens sometimes exserted, adnate until the median third of the corolla tube; filaments violet, dorsal ones 1.70-2.40 $\times 0.08 \mathrm{~cm}$, ventral ones $2.00-2.50 \times 0.08 \mathrm{~cm}$; thecae $0.15 \mathrm{~cm}$ diam.; staminodium $0.5-$ $1.1 \mathrm{~cm}$, adnate until the middle third of the corolla tube, glabrous. Ovary $0.5 \times 0.2 \mathrm{~cm}$; style $4.0-5.5 \mathrm{~cm}$, sometimes exserted, glabrous. Capsule 1.5-1.7 $\times 0.7-1.0 \mathrm{~cm}$, green or tinged purple. Seeds $0.10 \times$ $0.04 \mathrm{~cm}$.

\section{Distribution}

Three populations of Ameroglossum bicolor sp. nov. are known from granite outcrops in the municipalities of Agrestina, Bonito and Caruaru in the Agreste mesoregion of Pernambuco State, Brazil. It grows at elevations between 425 and $700 \mathrm{~m}$. 


\section{Ecology}

Ameroglossum bicolor sp. nov. has been collected in flower from May to October, with high inter- and intrapopulational synchrony (Wanderley et al. 2014a).

\section{Population and threats}

A population of 70 adult individuals is known from a granite outcrop known as Lajedo do Boi in the municipality of Agrestina; at least 40 individuals are known from the Pedra do Guariba granite outcrop in the municipality of Caruaru (Wanderley et al. 2014a); four other individuals were also located in Caruaru at Serra da Quitéria; 50 adult individuals are estimated to compose the population in the municipality of Bonito, all in Pernambuco State, Brazil. Main threats to these populations are habitat destruction through trampling by domestic animals, burning and other agricultural activity.

\section{Ameroglossum fulniorum E.M.Almeida, A.M.Wanderley \& L.P.Felix sp. nov. urn:lsid:ipni.org:names:77216328-1}

Figs 2D, 4d-g

\section{Diagnosis}

This species is similar to $A$. manoelfelixii in having lustrous, purple-tinged vegetative parts and scarlet flowers, but it differs in having inflorescences in simple dichasia (vs compound dichasia), peduncle winged (vs peduncle not winged) and white trichomes on the lower lip of the corolla (vs trichomes violet). It differs from the other species of Ameroglossum by the deep vinaceous colour of its vegetative parts.

\section{Etymology}

The specific epithet is dedicated to the Fulni-ô Amerindians whose territories are located in the Serra do Comunaty where the type material was collected. Members of the Fulni-ô ethnic group have conserved many of their traditional cultural values, being one of the few indigenous groups in north-eastern Brazil that have conserved their original language, Yaathe or Ia-tê, from the Macro-Jê linguistic branch.

\section{Material examined}

\section{Type}

BRAZIL - Pernambuco • Águas Belas, Quilombo; 0904'11" S, 3700'43" W; 903 m a.s.1.; 21 Aug. 2012; E.M. Almeida \& A.M. Wanderley 439; holotype: EAN!; isotype K!.

\section{Description}

Saxicolous chamaephyte up to $80 \mathrm{~cm}$, occasionally with secondary branching along the stem. Young branches purplish, lustrous, quadrangular, not winged, glabrescent, trichomes aciculate; brownish when mature, slightly inclined to incumbent, subquadrangular. Leaves opposite, decussate; leaf blade 6.0$14.5 \times 1.2-3.9 \mathrm{~cm}$, purplish when young, later greenish, lustrous, narrowly elliptic to elliptic, rarely narrowly trullate, slightly bullate; adaxial side glabrous; abaxial side glabrescent with papillose trichomes, principally the youngest leaves, rarely with recurved trichomes; apex sharply acuminate, flat to reflexed; margin flat to revolute, ciliate. Inflorescences in simple dichasia. Peduncle purplish, subcylindrical, winged, glabrescent, with papillose trichomes; primary peduncle $0.70-1.80 \times 0.10-0.14 \mathrm{~cm}$, secondary peduncle $0.3-0.8 \times 0.1 \mathrm{~cm}$. Pedicel $0.50-1.20 \times 0.10-0.15 \mathrm{~cm}$, purplish, glabrescent, with papillose trichomes, ventral side without wings. Bracts $0.10-0.30 \times 0.05-0.08 \mathrm{~cm}$, purplish, glabrescent, with papillose trichomes, margin glabrous. Calyx purplish, abaxial side glabrescent, with trichomes recurved and papillose, adaxial side densely covered by papillose trichomes, margin glabrous; sepals lanceolate, dorsal sepal $1.2-1.7 \times 0.3 \mathrm{~cm}$, lateral ones $1.0-1.3 \times 0.2 \mathrm{~cm}$, ventral ones $1.0-1.2 \times 0.2-0.3 \mathrm{~cm}$. Corolla 
$5.0-5.6 \mathrm{~cm}$ long, scarlet, externally glabrescent, with trichomes glandular and papillose, internally glabrous; tube 4.0-4.2 cm long; upper lip 1.3-1.8 × 0.9-1.1 cm; lower lip 1.3-1.5 × 0.4-0.5 cm, inner perianth with trichomes filiform, white; lobes revolute, median lobe $0.2-0.3 \times 0.1 \mathrm{~cm}$. Stamens included, adnate to the median third of the corolla tube; filaments violet, dorsal ones $2.00-2.70 \times 0.08 \mathrm{~cm}$, ventral ones $2.20-2.60 \times 0.08 \mathrm{~cm}$; thecae $0.15 \mathrm{~cm}$ diam.; staminodium $0.2-0.5 \mathrm{~cm}$, adnate to the proximal third of the corolla tube, glabrous. Ovary $0.60-0.80 \times 0.24-0.30 \mathrm{~cm}$; style $4.2-5.1 \mathrm{~cm}$, occasionally exserted, glabrous. Capsule 1.5-2.1 × 0.7-1.0 cm, purplish. Seeds $0.10 \times 0.04 \mathrm{~cm}$.

\section{Distribution}

Only two populations of A. fulniorum sp. nov. are known growing near Águas Belas, Serra do Comunaty, in the Agreste mesoregion of Pernambuco State, Brazil. Elevation ca $900 \mathrm{~m}$.

\section{Ecology}

Like other species of Ameroglossum, the occurrence of A. fulniorum sp. nov. is restricted to granite outcrops. Flowering and fruiting in August.

\section{Population and threats}

Only two populations of $A$. fulniorum sp. nov. are currently known, which together comprise approximately 40 widely spaced adult individuals. Due to the isolation of those populations and their restricted distributions, together with environmental pressure from trampling by domestic animals and the occasional passage of wildfires, this species is highly threatened.

\section{Ameroglossum genaroanum E.M.Almeida, J.M.P.Cordeiro \& L.P.Felix sp. nov. urn:lsid:ipni.org:names:77216329-1}

Figa 2E, 5a-d

\section{Diagnosis}

This species is morphologically similar to A. manoelfelixii in having young leaves with revolute margins, vegetative structures lustrous and violet trichomes on the lower lip of the corolla tube. It differs from that species in its green vegetative portions (vs tinged purple), leaf blade elliptic to ovate (vs elliptic to narrowly elliptic, sometimes trullate) and flowers orangish (vs scarlet).

\section{Etymology}

The specific name is in honour of Prof. Genaro Viana Dornelas, a senior professor at the Universidade Federal da Paraíba, who has a vast knowledge of the flora of Paraíba State.

\section{Material examined}

Type

BRAZIL - Paraíba • Tacima, Sítio Pão de Açúcar; 06³5'33"S, 35²7'38"W; 198 m a.s.1.; 28 Jul. 2012; E.M. Almeida, E.M. Almeida \& S.L.M. Almeida 397; holotype: EAN!; isotypes: IPA!, K!, RB!, UFP!.

\section{Paratypes}

BRAZIL - Paraíba • Serra da Raiz, Zona Urbana; 0641'07" S, 35²6'44" W; 341 m a.s.1.; 23 May 2018; L.P. Felix, E.M. Almeida \& J.M.P. Cordeiro 17,486; EAN[25,542]!. - Rio Grande do Norte • Santo Antônio, Serra da Micaela; 06¹8'03" S, 35³1'49" W; 295 m a.s.l.; 13 Apr. 2010; L.P. Felix 13041;

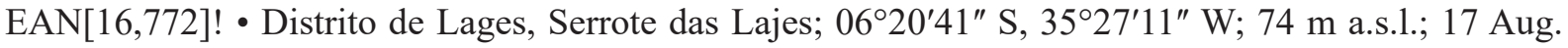
2013; J.L. Costa-Lima 1011; UFP[80,126]! • Estrada para Goianinha; 06 $19^{\prime} 15^{\prime \prime} \mathrm{S}, 35^{\circ} 27^{\prime} 09^{\prime \prime} \mathrm{W}$; $102 \mathrm{~m}$ a.s.1.; 13 Apr. 2010; L.P. Felix 13044; EAN[13,044]! Serra da Micaela; 06¹8'03" S, 35³1'49" W; 295 m a.s.1.; 2008; P.A. Porto s.n.; EAN[15972]! • Serrinha; 06 $16^{\prime} 42^{\prime \prime} \mathrm{S}, 35^{\circ} 29^{\prime} 58^{\prime \prime} \mathrm{W} ; 102 \mathrm{~m}$ a.s.1.; 16 Apr. 2003; S. Pitrez et al. 365; EAN[10281]!. 


\section{Description}

Saxicolous chamaephyte up to $100 \mathrm{~cm}$ tall, frequently with secondary branching near the tips. Young branches green, lustrous, occasionally bicolor with wide longitudinal purplish stripes, quadrangular, sometimes with a narrow wing, glabrous; brown cinereous when mature, slightly inclined, subquadrangular. Leaves opposite decussate; leaf blade 5.8-11.7× 2.2-4.3 cm, green, lustrous, elliptic to ovate, bullate when young, later smooth; adaxial side glabrous; abaxial side glabrescent, principally the younger leaves, with glandular trichomes; apex acute to acuminate, flat to reflexed; margin flat to revolute, ciliate. Inflorescences simple dichasia, sometimes compound. Peduncle green, cylindrical, without wings, glabrescent, with papillose trichomes; primary peduncle $0.8-2.8 \times 0.15 \mathrm{~cm}$, secondary

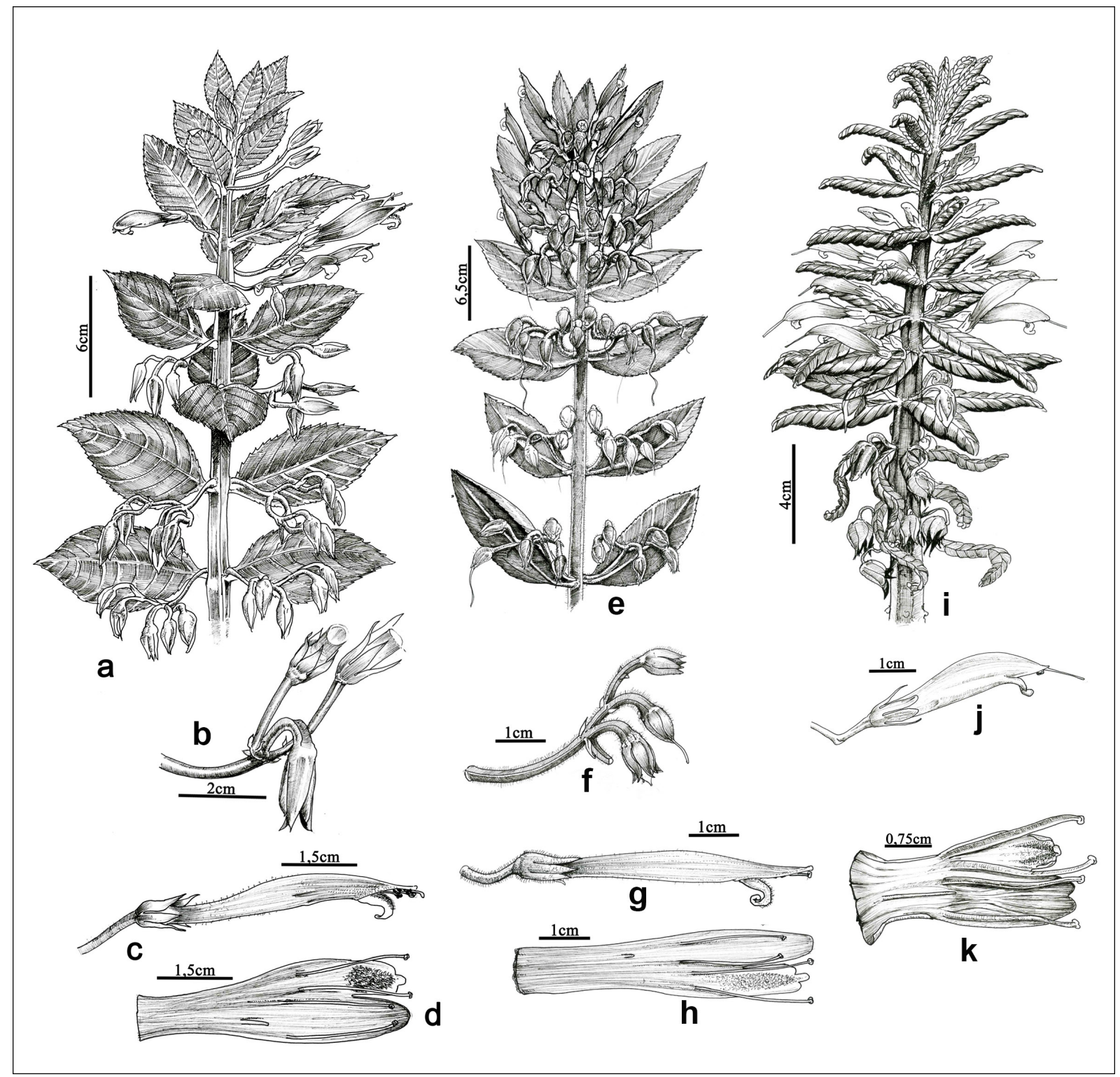

Fig. 5. a-d. Ameroglossum genaroanum sp. nov. (Almeida et al. 397). a. Reproductive branches. b. Inflorescence. c. Flower. d. Corolla opened, showing the stamens. e-h. Ameroglossum intermedium sp. nov. (Almeida \& Wanderley 478). e. Reproductive branches. f. Inflorescence. g. Flower. h. Corolla opened, showing the stamens. i-k. Ameroglossum xukuruorum sp. nov. (Felix et al. 15647). i. Reproductive branches. j. Flower. k. Corolla opened, showing the stamens. 
peduncle $0.4-1.1 \times 0.1 \mathrm{~cm}$, tertiary peduncle $0.40-0.60 \times 0.08 \mathrm{~cm}$. Pedicel $0.4-0.9 \times 0.1-0.2 \mathrm{~cm}$, green, glabrescent, with papillose trichomes, ventral side without wings. Bracts $0.20-0.70 \times 0.05-0.08 \mathrm{~cm}$, green, abaxial side glabrescent, with aciculate trichomes, adaxial side glabrescent, with papillose and aciculate trichomes, margin glabrous. Calyx green, abaxial side glabrescent, with papillose trichomes, adaxial side densely covered by papillose trichomes, margin ciliate with recurved trichomes; sepals lanceolate, dorsal one 1.1-1.8 $\times 0.3-0.5 \mathrm{~cm}$, lateral ones $0.8-1.4 \times 0.2 \mathrm{~cm}$, ventral ones $0.8-1.4 \times$ $0.2-0.4 \mathrm{~cm}$. Corolla $4.5-5.5 \mathrm{~cm}$ long, orangish with yellow base, externally pubescent with glandular trichomes, internally glabrous; tube 3.3-4.2 cm long; upper lip 1.4-1.6 $\times 0.8-0.9 \mathrm{~cm}$, slightly bilobate; lower lip $0.9-1.3 \times 0.4-0.5 \mathrm{~cm}$, inner perianth with filiform trichomes, violet; lobes revolute, median lobe $0.12-0.15 \times 0.08-0.10 \mathrm{~cm}$. Stamens included, sometimes with ventral pair exserted, adnate to the middle third of the corolla tube; filaments violet, dorsal ones $1.7-2.3 \times 0.7 \mathrm{~cm}$, ventral ones $1.7-2.1 \times$ $0.7 \mathrm{~cm}$; thecae ca $0.2 \mathrm{~cm}$ diam.; staminodium $0.3-0.5 \mathrm{~cm}$ long, adnate near the proximal third of the corolla tube, glabrescent with short, glandular trichomes. Ovary $0.6-0.8 \times 0.2-0.3 \mathrm{~cm}$; style $3.3-4.6 \mathrm{~cm}$ long, exserted. Capsule 1.2-1.5 $\times 0.6-0.8 \mathrm{~cm}$, green. Seeds $0.10 \times 0.05 \mathrm{~cm}$.

\title{
Distribution
}

This taxon has a more northerly distribution than the other species of Ameroglossum and occurs the lowest for this genus. It occurs on rock outcrops in the Agreste Paraibano mesoregion, in Paraíba State (two populations), and in the Agreste Potiguar mesoregion in Rio Grande do Norte State (four populations), Brazil. Elevation between 70 and $300 \mathrm{~m}$.

\section{Ecology}

Ameroglossum genaroanum sp. nov. occurs on rock outcrops. Flowering and fruiting between April and June.

\section{Population and threats}

Ameroglossum genaroanum sp. nov. is represented only by small isolated populations with up to 60 individuals distributed in small geographical areas susceptible to various anthropic impacts.

\author{
Ameroglossum intermedium E.M.Almeida, A.M.Wanderley \& L.P.Felix sp. nov. \\ urn:lsid:ipni.org:names:77216330-1 \\ Figs $2 \mathrm{~F}, 5 \mathrm{e}-\mathrm{h}$
}

\section{Diagnosis}

Ameroglossum intermedium sp. nov. combines characters of both A. manoelfelixii and A. pernambucense. It can be distinguished from $A$. manoelfelixii by its puberulent branches and leaves (vs glabrousglabrescent leaves), with acicular trichomes recurved at the apex (vs papillose trichomes), and from A. pernambucense by its compound dichasial inflorescence (vs a simple dichasium) and the revolute lower lip (vs involute).

\section{Etymology}

The specific epithet is derived from the Latin adjectives 'inter', 'between', and 'medius', 'middle', referring to the morphological characteristics of the new species that are intermediate between A. manoelfelixii and A. pernambucense.

\section{Material examined}

Type

BRAZIL-Alagoas • Quebrangulo; 09¹8'17" S, 36³1'13" W; 502 m a.s.1.; 23 Aug. 2012; E.M. Almeida \& A.M. Wanderley 478; holotype: EAN!; isotypes: IMA!, IPA!, K!, RB!. 


\section{Other material}

BRAZIL - Alagoas • Quebrangulo, estrada para Bom Retiro; 09¹7'56" S, 36³0'33" W; 25 Aug. 2013; L.P. Felix \& E.M. Almeida 14,339; EAN[19,860]!.

\section{Description}

Saxicolous chamaephyte up to $150 \mathrm{~cm}$, frequently with secondary branching along the stem. Young branches green to slightly purplish, bifacial, dull, quadrangular or hexangular, often narrowly winged, pubescent, with recurved trichomes; brown cinereous when mature, slightly inclined to decumbent, subquadrangular. Leaves opposite, decussate, occasionally verticillate and then up to three leaves per node; leaf blade 5.1-14.0 × 1.4-3.9 cm, green, lustrous, elliptic to narrowly elliptic, rarely trullate, bullate when young, later smooth; adaxial side glabrous, abaxial side pubescent, with recurved trichomes; apex acute, rarely acuminate, flat to reflexed; margin revolute when young, later flat, ciliate. Inflorescence a compound dichasium, occasionally simple. Peduncle green or tinged purple, subcylindrical, winged, pubescent, with recurved trichomes; primary peduncle $0.7-4.0 \times 0.1-0.2 \mathrm{~cm}$, secondary peduncle 0.30 $1.80 \times 0.13-0.15 \mathrm{~cm}$, tertiary peduncle $0.30-1.20 \times 0.07-0.10 \mathrm{~cm}$. Pedicel $0.6-2.5 \times 0.1-0.2 \mathrm{~cm}$, green to slightly purplish, pubescent, with recurved trichomes; ventral side winged up to the proximal third. Bracts $0.20-0.60 \times 0.03-0.08 \mathrm{~cm}$, green, abaxial side glabrous, adaxial side glabrescent with papillose trichomes, margin ciliate with recurved trichomes. Calyx green, abaxial side glabrescent, with recurved and/or papillose trichomes, adaxial side covered by papillose trichomes, margin ciliate with recurved trichomes; sepals lanceolate, dorsal one 1.2-1.5 ×0.3-0.5 cm, lateral ones 1.0-1.2 $\times 0.2 \mathrm{~cm}$, ventral ones $0.8-1.1 \times 0.2-0.3 \mathrm{~cm}$. Corolla $4.5-5.6 \mathrm{~cm}$ long, orangish, with proximal third yellowish, external side pubescent, trichomes glandular, rarely recurved and/or papillose; tube 3.5-4.4 cm long; upper lip $1.2-1.8 \times 0.6-0.8 \mathrm{~cm}$, slightly bilobate; lower lip $1.1-1.4 \times 0.35-0.50 \mathrm{~cm}$, inner perianth with white filiform trichomes; lobes revolute, median lobe $0.1 \times 0.2 \mathrm{~cm}$. Stamens occasionally with the ventral pair exserted, adnate to the median third of the corolla tube; filaments violet, dorsal ones $1.6-2.6 \times 0.8 \mathrm{~cm}$, ventral ones $1.9-2.9 \times 0.8 \mathrm{~cm}$; thecae ca $0.2 \mathrm{~cm}$ diam.; staminodium $0.3-0.4 \mathrm{~cm}$, adnate to the median third of the corolla tube, glabrous. Ovary $0.4-0.7 \times 0.2-0.3 \mathrm{~cm}$; style $3.6-5.6 \mathrm{~cm}$, occasionally exserted. Capsule 1.2-1.6 $\times 0.6-0.8 \mathrm{~cm}$, greenish. Seeds $0.10 \times 0.05 \mathrm{~cm}$.

\section{Distribution}

Only two populations of Ameroglossum intermedium sp. nov. are currently known, both in the municipality of Quebrangulo, Agreste mesoregion of Alagoas State. Elevation ca $500 \mathrm{~m}$.

\section{Ecology}

This species occurs exclusively on granite outcrops. Flowering and fruiting recorded in August and like all other Ameroglossum species it is pollinated by hummingbirds. The surrounding vegetation was probably originally composed of deciduous forest, but this has now been replaced by natural pasture.

\section{Population and threats}

Only two rock outcrops separated by pasture in a single municipality in Alagoas State are known to harbour this species. Approximately 200 adult individuals can be found in the first population, whereas the other comprises approximately 30 individuals. The main threat to these populations are farming and grazing of the site by stray animals.

\section{Taxonomic notes}

Among the species of Ameroglossum with quadrangular stems, A. intermedium sp. nov. stands out by having reproductive and vegetative structures covered in trichomes, a characteristic otherwise typically observed in A. pernambucense. However, A. intermedium sp. nov. differs by having leaves that are principally opposite and decussate, inflorescences of compound dichasia and the revolute lower lip. 
Ameroglossum manoelfelixii L.P.Felix \& E.M.Almeida

Fig. 2G

Systematic Botany 41: 423-429. (Almeida et al. 2016). - Type: BRAZIL - Paraíba • Esperança, Distrito de Lagoa de Pedra, Fazenda Timbaúba; 3552'50.3" W, 701'0.8” S; 699 m a.s.1.; 30 Aug. 2013; E.M. Almeida \& H.C.M. Oliveira 785; holotype: EAN!.

\section{Etymology}

The specific epithet was given in honor of Prof. Manoel Felix da Silva, of the Universidade Federal da Paraíba, an enthusiastic botanist.

\section{Material examined}

\section{Paratypes}

BRAZIL - Paraíba • Remígio, Agreste dos Coelhos; 20 Sep. 1959; J.C. Morais s.n.; EAN! • Pedra do Caboclo; 19 Jun. 1977; P.C. Fevereiro \& V.P.B. Fevereiro 28; EAN! • Remígio, Agreste dos Coelhos; 5 Aug. 1988; L.P. Felix \& L.T. Silva 1392; EAN! • Esperança, Lagoa de Pedra; 23 Jul. 1991; L.P. Felix 4040; EAN! • Fazenda Timbaúba; $7^{\circ} 00^{\prime} \mathrm{S}, 35^{\circ} 53^{\prime} \mathrm{W} ; 20$ Aug. 2009; A.M. Wanderley \& L.P. Felix s.n.; UFP! - Areia, Assentamento Rural Emanuel Joaquim; 19 Jul. 2012; E.M. Almeida 385; EAN! • Puxinanã; 21 Jul. 2012; E.M. Almeida \& W.C. Silva 392; EAN! • Bananeiras; Fazenda Jatobá; 35 36'02" W, 6²5'20" S; 509 m a.s.1.; 29 Jul. 2012; E.M. Almeida 412; EAN!

\section{Description}

Saxicolous chamaephyte up to $3 \mathrm{~m}$, occasionally with secondary branching along the stem. Young branches purplish, lustrous, quadrangular, winged, glabrous; when mature brownish, slightly inclined, subquadrangular. Leaves opposite, decussate (rarely ternate); leaf blade 4.0-15.0 $\times 3.3-4.8 \mathrm{~cm}$, purplish when young, later greenish, lustrous, elliptic to narrowly elliptic, sometimes trullate, slightly bullate; younger leaves densely covered by papillose trichomes, later glabrous; apex acuminate to acute, often cirrhose; margin revolute when young, later flat, ciliate. Inflorescence a compound dichasium. Peduncle purplish, cylindrical, without wings, glabrous; primary peduncle $0.8-2.5 \times 0.15 \mathrm{~cm}$, secondary peduncle $0.5-1.1 \times 0.1 \mathrm{~cm}$, tertiary peduncle $0.5-0.7 \times 0.1 \mathrm{~cm}$. Pedicel $0.8-1.0 \times 0.1 \mathrm{~cm}$, purplish, glabrous, ventral side without wings. Bracts $0.3-0.7 \times 0.8 \mathrm{~cm}$, purplish, glabrous. Calyx purplish, abaxial side glabrescent with papillose trichomes, abaxial side densely covered by papillose trichomes, sepals lanceolate, dorsal one $1.5-1.8 \times 0.3-0.5 \mathrm{~cm}$, lateral ones $1.1-1.3 \times 0.2-0.3 \mathrm{~cm}$, ventral ones $0.8-1.1 \times$ $0.2-0.4 \mathrm{~cm}$. Corolla $5.0-5.7 \mathrm{~cm}$ long, scarlet, externally glabrous to densely covered by papillose trichomes, internally glabrescent with papillose trichomes; tube 3.5-4.0 cm, upper lip 1.5-1.7 $\times 0.8$ $0.9 \mathrm{~cm}$, slightly bilobate; lower lip $0.9-1.3 \times 0.4-0.5 \mathrm{~cm}$, yellow, rarely with scarlet margins, inner perianth with trichomes filiform, violet; lobes revolute; median lobe ca $0.15 \times 0.10 \mathrm{~cm}$. Stamens with ventral pair exserted and dorsal pair enclosed, adnate to the median third of the corolla tube; filaments $1.8-3.5 \mathrm{~cm}$, violet; thecae $0.2 \mathrm{~cm}$ diam.; staminodium $0.30 \times 0.02 \mathrm{~cm}$, adnate at the median third of the corolla tube, glabrous. Ovary $0.7-1.0 \times 0.2-0.4 \mathrm{~cm}$; style $4.0-5.5 \mathrm{~cm}$, slightly exserted. Capsule $1.4-1.3 \times 0.5-0.6 \mathrm{~cm}$, purplish. Seeds $0.10 \times 0.05 \mathrm{~cm}$.

\section{Distribution}

Ameroglossum manoelfelixii occurs exclusively on granite outcrops in Paraíba State, restricted to the Agreste da Borborema, Curimataú and Brejo microregions. Elevation between 500 and $700 \mathrm{~m}$.

\section{Ecology}

This species is pollinated by hummingbirds (Wanderley et al. 2020). It has been collected with flowers and fruits between March and August. 


\section{Population and threats}

This species has a fragmented distribution and its populations are under intense anthropogenic pressure. Many rock outcrops where the species occurs have been quarried for cobblestones, and many populations are on farms where the vegetation is trampled and grazed by livestock. Fires are also often set to these vegetation islands for no clear purpose.

Ameroglossum pernambucense Eb.Fisch., S.Vogel \& A.Lopes

Fig. $2 \mathrm{H}$

Feddes Repertorium 110: 529-534 (Fischer et al. 1999). - Type: BRAZIL - Pernambuco • Brejo da Madre de Deus, próximo ao Brejo do Bituri; $8^{\circ} 09^{\prime} 00^{\prime \prime}$ S, 36 $26^{\circ} 2^{\prime} 15^{\prime \prime}$ W; ca 800 m a.s.l.; 19 Aug. 1998 ; S. Vogel 1998-46; holotype UFP!; isotype WU.

\section{Etymology}

The specific epithet refers to the state of Pernambuco, where the type material was collected.

\section{Material examined}

BRAZIL - Pernambuco • Brejo da Madre de Deus, Propriedade de Bituri; 15 Sep. 1973; D. de AndradeLima 73-7,439; IPA[29,676]! • Brejo da Madre de Deus; 31 Oct. 2005; L.P. Felix 10819; EAN[11,302]! • ibid.; 26 Feb. 2006; L.P. Felix 10989; EAN[12,054]! • ibid.; 9 Sep. 2008; L.P. Felix 12536; EAN[15,385]! - Bitury; 08 11'49" S, 36²4'19" W; 1135 m a.s.1.; 23 Oct. 2008; L.P. Felix 12586-1; EAN[15,778]! • ibid.; 15 Sep. 2010; L.P. Felix \& E.M. Almeida 13150; EAN[16,773]! • Fazenda Bitury, Divisa da Malhada com Teixeira; 08 $12^{\prime} 01^{\prime \prime}$ S, 36 24'13" W; 1005 m a.s.1.; 11 Nov. 2003; J.A. Siqueira-Filho 1403; UFP[39,363]! • São Caetano; 08²1'51" S, 3603'44" W; 1020 m a.s.1.; 2 Jul. 2015; L.P. Felix et al. 15687; EAN!

\section{Description}

Saxicolous chamaephyte up to $2 \mathrm{~m}$, frequently with secondary branching along the stem. Young branches green to slightly purplish, dull, slightly angular, often narrowly winged, villose, trichomes bifid; cinereous when mature, slightly inclined to decumbent, cylindrical. Leaves verticillate, usually three or four per node, rarely opposite and then only on secondary branches; leaf blade 5.2-7.5 × 1.0-1.2 cm, green, rarely slightly purplish, dull to lustrous, elliptic to narrowly elliptic, rarely lanceolate, bullate; adaxial side glabrescent, with papillose trichomes; abaxial side villose, with bifidly ramified trichomes; apex acute to acuminate, flat; margin flat to revolute, ciliate. Inflorescence a simple dichasium. Peduncle green to slightly purplish, cylindrical, slightly winged, villose, with trichomes aciculate and bifid; primary peduncle $0.3-1.4 \times 0.1 \mathrm{~cm}$, secondary peduncle $0.3-0.5 \times 0.1 \mathrm{~cm}$. Pedicel $0.3-0.8 \times 0.1 \mathrm{~cm}$, green to slightly purplish, villose, with trichomes aciculate and bifid; ventral side without wings. Bracts $0.15-0.30 \times 0.05 \mathrm{~cm}$, green to slightly purplish; abaxial side pubescent, with trichomes aciculate and/or bipinnate, adaxial side glabrescent, with papillose trichomes. Calyx green to slightly purplish, abaxial side pubescent with trichomes aciculate and/or bipinnate, adaxial side densely covered by papillose trichomes, sepals lanceolate, dorsal one $0.50-0.80 \times 0.25 \mathrm{~cm}$, lateral ones $0.5-0.8 \times 0.2 \mathrm{~cm}$, ventral ones $0.50-0.80 \times 0.15 \mathrm{~cm}$. Corolla $2.5-3.5 \mathrm{~cm}$, dorsal and lateral tube orangish with ventral and proximal third yellow, base wide, externally pubescent, with trichomes short, glandular, internally glabrous; tube 2.0-2.9 cm; upper lip 0.5-0.7 $\times 0.5-0.6 \mathrm{~cm}$, bilobate; lower lip 0.5-0.6 $\times 0.4 \mathrm{~cm}$, inner perianth with trichomes conical, yellowish white; lobes involute, median lobe $0.15 \times 0.10 \mathrm{~cm}$. Stamens excerted, adnate at the proximal third of the corolla tube; filaments white, dorsal ones $2.8-3.0 \times 0.8 \mathrm{~cm}$, ventral ones 2.2-2.6 $\times 0.8 \mathrm{~cm}$; thecae ca $0.1 \mathrm{~cm}$ diam.; staminodium ca $1 \mathrm{~cm}$, adnate at the proximal third of the corolla tube, glabrescent with papillose trichomes. Ovary $0.3-0.5 \times 0.2 \mathrm{~cm}$; style up to $3.4-4.0 \mathrm{~cm}$, exserted, glabrous. Capsule 1.1-1.3 $\times 0.5-0.7 \mathrm{~cm}$, green to slightly purplish. Seeds $0.10 \times 0.05 \mathrm{~cm}$. 


\section{Distribution}

Ameroglossum pernambucense is restricted to the municipalities of Brejo da Madre de Deus and São Caetano, Agreste mesoregion of Pernambuco State. Elevations between 1000 and $1150 \mathrm{~m}$.

\section{Ecology}

Plants are saxicolous on tall granite rocks. Flowering from March to October, with flowering peak in July, and pollinated by hummingbirds (Wanderley et al. 2014a, 2020).

\section{Population and threats}

The populations known typically comprise approximately 50 mature plants. Other populations have been observed on rock outcrops nearby. The fragmented subpopulations are often subjected to trampling by cattle and long periods of drought.

\section{Taxonomic notes}

Ameroglossum pernambucense is the type species and differs from the other species proposed here principally in having verticillate, villose leaves (vs opposite leaves); apart from A. xukuruorum sp. nov., which has verticillate, glabrous leaves and the slighty apically trilobed lower lip of the corolla (vs lower lip entire to slightly crenate).

\section{Ameroglossum xukuruorum E.M.Almeida, Christenh. \& L.P.Felix sp. nov. urn:lsid:ipni.org:names:77216331-1}

Figs 2I, 5i-k

\section{Diagnosis}

Ameroglossum xukuruorum sp. nov. is similar to A. pernambucense in having verticillate leaves and involute lobes on the lower lip. It differs by its glabrous or glabrescent vegetative portions (vs villose) and usually lanceolate leaf blade with sparsely branched venation (vs elliptic to narrowly elliptic and densely branched venation).

\section{Etymology}

The specific epithet is dedicated to the Amerindian Xukuru people, because the type material was collected with their assistance on tribal lands in the Serra do Ororubá Range.

\section{Material examined}

\section{Type}

BRAZIL - Pernambuco - Pesqueira, Serra do Ororubá, Reserva Indígena Xukuru de Cimbres; $08^{\circ} 19^{\prime} 15^{\prime \prime} \mathrm{S}, 36^{\circ} 46^{\prime} 12^{\prime \prime} \mathrm{W}$; $1122 \mathrm{~m}$ a.s.1.; 30 Jun. 2015; L.P. Felix et al. 15647; holotype: EAN!; isotypes: IPA!, K!, RB!, UFP!.

\section{Paratypes}

BRAZIL - Paraíba • São João do Tigre, Serra do Paulo; 0805'35" S, 36²40'35" W; 1193 m a.s.1.; 16 Jul. 2010; L.P. Felix \& L.I.F. Alves 13085; EAN[16,438]! • ibid.; 23 Aug. 2013; L.P. Felix 14318; EAN[19,895]! • ibid.; 3 Aug. 2011; S. Nascimento 105; EAN[18,513]! • Serra do Enjeitado; 4 Aug. 2011; S. Nascimento 168; EAN[18,173]! • Serra do Paulo; 0805'36" S, 36³8'34" W; 1094 m a.s.1.; 4 Aug. 2011; S. Nascimento 151; EAN[18,555]! - Pernambuco • Pesqueira, Serra do Ororobá; 2 Aug. 1979; D. de Andrade-Lima et al. 79-9,659; IPA[46,742]! • Serra do Gavião; \pm 800 m a.s.1.; 19 Jun. 2005; M. Oliveira 1,817; UFP[41,495]! • Jataúba, Sítio Sobrado; 0804'53" S, 36³4'48" W; 1021 m a.s.1.; 6 Jun. 2016; E.M. Almeida, L.I.F. Alves \& J.A.L. Neves 1673; EAN[24,603]!. 


\section{Description}

Saxicolous chamaephyte up to $80 \mathrm{~cm}$, occasionally with some secondary branching at the branch tips. Young branches slightly purplish, dull, slightly angular, often narrowly winged, covered by inconspicuous papillose trichomes; mature branches cinereous, slightly inclined to decumbent, cylindrical. Leaves verticillate with usually four leaves per node; leaf blade $2.5-8.2 \times 0.5-1.4 \mathrm{~cm}$, green, cinereous, lustrous, narrowly elliptic to lanceolate, sometimes elliptic, bullate; adaxial side glabrous; abaxial side glabrous to glabrescent, with trichomes aciculate and/or papillose; apex acute to acuminate, recurved; margin revolute when young, later flat to revolute; glabrous. Inflorescences in simple dichasia, frequently unifloral. Peduncle slightly purplish to green, cylindrical, glabrous; primary peduncle 0.25 $1.10 \times 0.05-0.08 \mathrm{~cm}$, secondary $0.2-0.3 \times 0.7 \mathrm{~cm}$. Pedicel $0.3-0.5 \times 0.1 \mathrm{~cm}$, slightly purplish to green, glabrous; ventral side without wings. Bracts $0.10-0.30 \times 0.05 \mathrm{~cm}$, purplish to green, glabrous. Calyx slightly purplish to green, glabrous; sepals lanceolate, dorsal one $0.75-1.10 \times 0.10-0.20 \mathrm{~cm}$, lateral ones $0.60-1.00 \times 0.15-0.20 \mathrm{~cm}$, ventral ones $0.60-1.00 \times 0.10-0.25 \mathrm{~cm}$. Corolla $2.5-3.4 \mathrm{~cm}$, adaxial portion orange-red, ventral portion and proximal third yellow, base wide, glabrous; tube 2-3 cm; upper lip $0.55-0.75 \times 0.06-0.10 \mathrm{~cm}$, bilobate; lower lip, inner perianth with trichomes conical, yellowish white; lobes involute, median lobe $0.15 \times 0.04 \mathrm{~cm}$. Stamens exserted, adnate at the median third of the corolla tube; filaments white, $1.8-3.5 \mathrm{~cm}$ long; thecae ca $0.15 \mathrm{~cm}$ diam.; staminodium ca $0.3 \mathrm{~cm}$, adnate at the proximal third of the corolla tube, glabrescent, with short-glandular trichomes, rarely papillose. Ovary $0.40-0.50 \times 0.15-0.30 \mathrm{~cm}$; style $2.4-3.3 \mathrm{~cm}$, exserted, glabrous. Capsule $0.9-1.0 \times 0.3-0.5 \mathrm{~cm}$, green to slightly purplish. Seeds $0.10 \times 0.05 \mathrm{~cm}$.

\section{Distribution}

Ameroglossum xukuruorum sp. nov. has only been collected above $1000 \mathrm{~m}$ a.s.l., which corresponds to the highest areas of the Borborema Plateau in the states of Paraíba (São João do Tigre in the Cariri Ocidental microregion) and Pernambuco (Pesqueira in the Vale do Ipojuca microregion). Elevation between (800-) 1000 and $1200 \mathrm{~m}$.

\section{Ecology}

Ameroglossum xukuruorum sp. nov. appears to prefer higher elevation habitats. It was encountered flowering and fruiting between April and August and is pollinated by hummingbirds (pers. obs.).

\section{Population and threats}

Ameroglossum xukuruorum sp. nov. is restricted to the municipalities of Jataúba, Pesqueira and São João do Tigre and has been collected in the Xukuru Indigenous Reserve on a rock outcrop covering approximately 50 ha, with a population of more than 100 individual adult plants. Additionally, the Serra do Ororubá Range, where the reserve is located, has a series of granite outcrops that are difficult to access, and it is possible that other populations of A. xukuruorum sp. nov. (or other species of Ameroglossum) are yet to be discovered there. The two known locations in Paraíba State have a total of ca 100 adult individuals. The isolated populations are exposed to burning and trampling by livestock.

\section{Discussion}

Ameroglossum (Linderniaceae, Lamiales) now comprises nine species. This is likely not to be the final total because we predict that there may be additional undescribed species among herbarium specimens or in regions that have not yet been investigated. Our survey of inselbergs in the region was extensive but by no means exhaustive, and it is thus possible that additional diversity is present.

This level of hidden diversity is not unique to Ameroglossum, because a similar unexpected diversity has been found in a number of plant and animal groups in north-eastern Brazil (e.g., Plowman 1986; 
Gonçalves-Oliveira et al. 2017; Mângia et al. 2018; Chagas \& da Costa-Lima 2020; Pinagé et al. 2020, etc.).

The drivers of this unexpectedly high diversity on these relatively dry granitic outcrops may be due to the isolation of these sites. These rock formations are ecologically islands, usually called inselbergs (Porembski \& Barthlott 2000), and this has often resulted in allopatric speciation and has been found in many groups of animals and plants typically found there, including Ameroglossum (Wanderley et al. 2018).

Pollinators also seem to be the drivers of the diversity of this genus (Wanderley et al. 2014a; Almeida et al. 2019). Further studies on pollinators of these new species of Ameroglossum, and of the related genus Isabelcristinia, are needed to elucidate this phenomenon. Speciation by hummingbird pollination has been shown to occur in several plant groups (e.g., Zung et al. 2015; Kessler et al. 2020; Kriebel et al. 2020). Because of the differences in corolla colour and lip-shape between these species, it is likely that this diversity is linked to specific hummingbird pollinators, but extensive field observations will be needed to better understand this relationship. Wanderley et al. (2020) studied pollination success of A. manoelfelixii and A. pernambucense in isolated populations and showed that both species selfpollinate. However, pollination by hummingbirds increased fecundity. Nevertheless, the limited crosspollination success (ca 3\%) suggested that Ameroglossum has a low capacity to counteract genetic erosion (Wanderley et al. 2020). This contrasts with the bromeliad Encholirium spectabile Mart. ex Schult. \& Schult.f., which is dominant in similar habitats where Ameroglossum is found and shows a unique genetic composition on each inselberg, although populations are still genetically linked (GonçalvesOliveira et al. 2017). This is due to differences in pollinators; Encholirium Mart. is pollinated by bats, resulting in the inselbergs being less isolated simply because bats have a larger range than hummingbirds (Wanderley et al. 2020) and are thus more likely to visit more than one inselberg.

Meanwhile, inselberg habitats are greatly threatened by cattle ranching, mining, invasive species and fire, and many species dependent on these vegetation islands are under great pressure (Porembski 2007; Wanderley et al. 2014b). Now that we know that Ameroglossum is not a single widespread species, but consists of a complex of at least nine species with limited distributions, it is adamant that in situ programmes are developed, protecting as many populations as possible. Currently, only $1.5 \%$ of the genetic diversity of the region lies within protected areas (Fonseca et al. 2019), and therefore, to maintain evolutionary potential in the region, areas with higher genetic diversity need to be included in future conservation planning, not only to safeguard the new species described here, but also to preserve these unique inselberg communities.

Ex situ conservation through horticulture is also an option because the species are easily cultivated, stems root readily in water (pers. obs.) and plants make attractive horticultural subjects, suitable for dry tropical and subtropical regions. As with other endangered plant species (e.g., Wollemia nobilis W.G.Jones, K.D.Hill \& J.M.Allen: Trueman et al. 2007), profits from the sale of plants propagated horticulturally may help fund the protection of inselberg habitats to the benefit of these species.

\section{Acknowledgements}

The authors thank the Conselho Nacional de Desenvolvimento Científico e Tecnológico (CNPq) and the Coordenação de Aperfeiçoamento de Pessoal de Nível Superior (CAPES) for their financial support, and the Instituto Nacional do Semiárido (INSA) for technical support. We thank Prof. Mark W. Chase for comments and revising the English of this manuscript. 


\section{References}

Almeida E.M., Wanderley A.M., Nollet F., Costa F.R., Souza L.G.R \& Felix L.P. 2016. A new species of Ameroglossum (Scrophulariaceae) growing on inselbergs. Systematic Botany 41 (2): 423-429. https://doi.org/10.1600/036364416X691740

Almeida E.M., Wanderley A.M., Santos A.D., De Melo J.I., Souza G., Batista F.R., Christenhusz M.J.M., Felix L.P. 2019. Two new genera and species of Linderniaceae (Lamiales) from inselbergs in northeastern Brazil: morphological and karyological evidence. Phytotaxa 400: 215-226.

https://doi.org/10.11646/phytotaxa.400.4.1

Andrade-Lima D. 1981. The caatingas dominium. Revista Brasileira de Botânica 4 (2): 149-153.

Barringer K. 1984. Cubitanthus, a new genus of Gesneriaceae from Brazil. Journal of the Arnold Arboretum 65: 145-147.

Cardoso P.H., Neto L.M. \& Salimena F.R.G. 2019a. A new species of Stachytarpheta (Verbenaceae) from an inselberg of Espírito Santo state, Brazil. Phytotaxa 400: 273-278.

https://doi.org/10.11646/phytotaxa.400.5.3

Cardoso P.H., Neto L.M. \& Salimena F.R.G. 2019b. A new species of Lippia (Verbenaceae) from the inselbergs of Brazilian Atlantic Forest. Phytotaxa 406: 243-249.

https://doi.org/10.11646/phytotaxa.406.4.3

Castellanos M.C., Wilson P. \& Thomson J.D. 2004. 'Anti-bee' and 'pro-bird'changes during the evolution of hummingbird pollination in Penstemon flowers. Journal of Evolutionary Biology 17 (4): 876-885. https://doi.org/10.1111/j.1420-9101.2004.00729.x

Chagas E.C. \& da Costa-Lima J.L. 2020. Five new species of Ruellia (Acanthaceae) from the Atlantic Forest of northeastern Brazil. Neodiversity 13: 39-55. https://doi.org/10.13102/neod.131.2

Christenhusz M.J.M., Fay M.F. \& Chase M.W. 2017. Plants of the World, an Illustrated Encyclopedia of Vascular Plants. Kew Publishing/Chicago University Press, Richmond, UK.

https://doi.org/10.7208/chicago/9780226536705.001.0001

Cordeiro J.M.P., Nollet F., Buril M.T., Chase M.W. \& Felix L.P. 2018. A new species of Gomesa (Oncidiinae, Orchidaceae) from inselbergs in Brazilian caatinga: morphological and karyological evidence. Phytotaxa 374: 147-154. https://doi.org/10.11646/phytotaxa.374.2.6

Corrêa A.C.B., Tavares B.A.C., Monteiro K.A., Cavalcanti L.C.S. \& de Lira DR. 2010. Megamorfologia e morfoestrutura do Planalto de Borborema. Revista do Instituto Geológico 31: 35-52.

https://doi.org/10.5935/0100-929X.20100003

Cronk Q. \& Ojeda I. 2008. Bird-pollinated flowers in an evolutionary and molecular context. Journal of Experimental Botany 59 (4): 715-727. https://doi.org/10.1093/jxb/ern009

De Lima E.L., Maia L.C., Martins M.C.B., da Silva N.L., Lücking R. \& Cáceres M.E.S 2019. Five new species of Graphidaceae from the Brazilian Northeast, with notes on Diorygma alagoense. The Bryologist 122: 414-422. https://doi.org/10.1639/0007-2745-122.3.414

Engler A. 1897. Contribuzioni alla conoscenza della flora dell'Africa orientale - XIV. Annuario del Reale Istituto botanico di Roma 7: 13-43.

Fischer E., Schäferhoff B. \& Müller K.F. 2013. The phylogeny of Linderniaceae - The new genus Linderniella, and new combinations within Bonnaya, Craterostigma, Lindernia, Micranthemum, Torenia and Vandellia. Willdenowia 43: 209-238. https://doi.org/10.3372/wi.43.43201

Fischer E., Vogel S. \& Lopes A.V. 1999. Ameroglossum, a new monotypic genus of ScrophulariaceaeScrophularioideae from Brazil. Feddes Repertorium 110: 529-534.

https://doi.org/10.1002/fedr.19991100713 
Fonseca E.M., Werneck F.P., Gehara M. Oliveira E.F., Magalhães F.M., Lanna F.M., Lima G.S., Marques R., Mesquita D.O., Costa G.C., Colli G.R. \& Garda A.A. 2019. The role of strict nature reserves in protecting genetic diversity in a semiarid vegetation in Brazil. Biodiversity and Conservation 28: 2877-2890. https://doi.org/10.1007/s10531-019-01802-y

Gonçalves E.G. \& Lorenzi H. 2007. Morfologia vegetal: Organografia e Dicionário ilustrado de Morfologia das Plantas vasculares. Instituto Plantarum de Estudos da Flora Ltda, Nova Odessa.

Gonçalves-Oliveira R.C., Wöhrmann T., Benko-Iseppon A.M., Krapp F., Alves M., Wanderley M.G.L. \& Weising K. 2017. Population genetic structure of the rock outcrop species Encholirium spectabile (Bromeliaceae): the role of pollination vs. seed dispersal and evolutionary implications. American Journal of Botany 104 (6): 868-878. https://doi.org/10.3732/ajb.1600410

Kessler M., Abrahamczyk S. \& Krömer T. 2020. The role of hummingbirds in the evolution and diversification of Bromeliaceae: unsupported claims and untested hypotheses. Botanical Journal of the Linnean Society 192 (4): 592-608. https://doi.org/10.1093/botlinnean/boz100

Kriebel R., Drew B., González-Gallegos J.G., Celep F., Heeg L., Mahdjoub M.M. \& Sytsma K.J. 2020. Pollinator shifts, contingent evolution, and evolutionary constraint drive floral disparity in Salvia (Lamiaceae): evidence from morphometrics and phylogenetic comparative methods. Evolution 74 (7): 1335-1355. https://doi.org/10.1111/evo.14030

Mângia S., Koroiva R., Nunes P.M., Roberto I.J., Ávila R.W., Sant'Anna A.C., Santana D.J. \& Garda A.A. 2018. A new species of Proceratophrys (Amphibia: Anura: Odontophrynidae) from the Araripe Plateau, Ceará State, northeastern Brazil. Herpetologica 74 (3): 255-268.

https://doi.org/10.1655/Herpetologica-D-16-00084.1

Morales J.F. \& Kollmann L.J. 2020. Increasing the known floristic diversity of Brazilian inselbergs: two new species of Mandevilla (Apocynaceae) from Espírito Santo. Acta Botanica Brasilica 34: 107-116. https://doi.org/10.1590/0102-33062019abb0241

Morales J.F. \& de Morais I.L. 2020. Studies in the Neotropical Apocynaceae LV: a new Mandevilla from Bahia, Brazil, with notes on the diversity of the genus. Systematic Botany 45: 183-189.

https://doi.org/10.1600/036364420X15801369352450

Payne W.W. 1978. A glossary of plant hair terminology. Brittonia 30: 239-255. https://doi.org/10.2307/2806659

Pinangé D.S., Louzada R.B., Wöhrmann T., Krapp F., Weising K., Zizka G., Polo É.M., Wanderley M.G. \& Benko-Iseppon A.M. 2020. Population genetics shed light on species delimitation and life history of the Dyckia pernambucana complex (Bromeliaceae). Botanical Journal of the Linnean Society 192 (4): 706-725. https://doi.org/10.1093/botlinnean/boz106

Plowman T. 1986. Four new species of Erythroxylum (Erythroxylaceae) from northeastern Brazil. Brittonia 38 (3): 189-200. https://doi.org/10.2307/2807336

Pontes R.A.S.D. 2012. Tillandsia paraibensis, uma nova espécie de Bromeliaceae do Nordeste do Brasil. Rodriguésia 63: 551-555. https://doi.org/10.1590/S2175-78602012000300006

Porembski S. 2007. Effects of anthropogenic disturbance on the vegetation of granitic and gneissic rock outcrops ('inselbergs') in West Africa. Nova Hedwigia 131: 237-246.

Porembski S. \& Barthlott W. 2000. Inselbergs: Biotic Diversity of Isolated Rock Outcrops in Tropical and Temperate Regions. Springer Verlag, Berlin, Heidelberg. https://doi.org/10.1007/978-3-642-59773-2

Radford A.E., Dickison W.C., Massey J.R. \& Bell C.R. 1974. Vascular Plant Systematics. Harper \& Row, New York. 
Santos F.D.S., Junior G.C.D., Báez M., Pedrosa-Harand A., Queiroz J.A., Quirino Z.G.M., Machado I.C. \& Buril M.T. 2019. Ipomoea vespertilia (Convolvulaceae), a new species revealed by pollinator observation. Brittonia 71: 190-195. https://doi.org/10.1007/s12228-018-09565-6

Souza V.C. \& Giulietti A.M. 2009. Levantamento das espécies de Scrophulariaceae sensu lato nativas do Brasil. Pesquisas Botânica 60: 7-288.

Available from http://www.lcb.esalq.usp.br/publications/articles/2009/2009pbv60p7-288.pdf [accessed 13 Mar. 2021].

Thiers B. continuously updated. Index Herbariorum: A Global Directory of Public Herbaria and Associated Staff. New York Botanical Garden's Virtual Herbarium.

Available from http://sweetgum.nybg.org/science/ih/ [accessed 13 Mar. 2021].

Thomson J.D. \& Wilson P. 2008. Explaining evolutionary shifts between bee and hummingbird pollination: convergence, divergence, and directionality. International Journal of Plant Sciences 169 (1): 23-38. https://doi.org/10.1086/523361

Trueman S.J., Pegg G.S. \& King J. 2007. Domestication for conservation of an endangered species: the case of the Wollemi pine. Tree and Forestry Science and Biotechnology 1: 1-10. Available from http://www.globalsciencebooks.info/Online/GSBOnline/images/0712/TFSB_1(1)/TFSB_1(1)1-10o.pdf [accessed 13 Mar. 2021].

Wanderley A.M., Almeida E.M. \& Felix L.P. 2014b. Ameroglossum pernambucense. The IUCN Red List of Threatened Species 2014: e.T56726171A56726230.

https://doi.org/10.2305/IUCN.UK.2014-1.RLTS.T56726171A56726230.en

Wanderley A.M., Lopes A.V. \& Machado I.C. 2014a. Reproductive ecology of Ameroglossum pernambucense (Scrophulariaceae): is this ornithophilous and threatened shrub highly adapted to a naturally fragmented habitat? Plant Systematics \& Evolution 300: 1099-1110.

https://doi.org/10.1007/s00606-013-0948-x

Wanderley A.M., Machado I.C.M., Almeida E.M., Felix L.P., Galetto L., Benko-Ippeson A.M. \& Sork V.L. 2018. The roles of geography and environment in divergence within and between two closely related plant species inhabiting an island-like habitat. Journal of Biogeography 45: 381-393.

https://doi.org/10.1111/jbi.13137

Wanderley A.M., dos Santos E.K., Galetto L., Benko-Iseppon A.M. \& Machado I.C. 2020. Pollen flow within and among isolated populations of two rare, self-compatible plant species from inselbergs of Northeast Brazil. Plant Ecology 221: 229-240. https://doi.org/10.1007/s11258-020-01004-5

Zung J.L., Forrest J.R., Castellanos M.C. \& Thomson J.D. 2015. Bee-to bird-pollination shifts in Penstemon: effects of floral-lip removal and corolla constriction on the preferences of free-foraging bumble bees. Evolutionary Ecology 29 (3): 341-354. https://doi.org/10.1007/s10682-014-9716-9

Manuscript received: 2 October 2020

Manuscript accepted: 8 December 2020

Published on: 15 April 2021

Topic editor: Frederik Leliaert

Desk editors: Connie Baak, Radka Rosenbaumová

Printed versions of all papers are also deposited in the libraries of the institutes that are members of the EJT consortium: Muséum national d'histoire naturelle, Paris, France; Meise Botanic Garden, Belgium; Royal Museum for Central Africa, Tervuren, Belgium; Royal Belgian Institute of Natural Sciences, Brussels, Belgium; Natural History Museum of Denmark, Copenhagen, Denmark; Naturalis Biodiversity Center, Leiden, the Netherlands; Museo Nacional de Ciencias Naturales-CSIC, Madrid, Spain; Real Jardín Botánico de Madrid CSIC, Spain; Zoological Research Museum Alexander Koenig, Bonn, Germany; National Museum, Prague, Czech Republic. 